\title{
Role Congruity Theory of Prejudice Toward Female Leaders
}

\author{
Alice H. Eagly \\ Northwestern University
}

\author{
Steven J. Karau \\ Southern Illinois University at Carbondale
}

\begin{abstract}
A role congruity theory of prejudice toward female leaders proposes that perceived incongruity between the female gender role and leadership roles leads to 2 forms of prejudice: (a) perceiving women less favorably than men as potential occupants of leadership roles and (b) evaluating behavior that fulfills the prescriptions of a leader role less favorably when it is enacted by a woman. One consequence is that attitudes are less positive toward female than male leaders and potential leaders. Other consequences are that it is more difficult for women to become leaders and to achieve success in leadership roles. Evidence from varied research paradigms substantiates that these consequences occur, especially in situations that heighten perceptions of incongruity between the female gender role and leadership roles.
\end{abstract}

Leadership has been predominantly a male prerogative in corporate, political, military, and other sectors of society. Although women have gained increased access to supervisory and middle management positions, they remain quite rare as elite leaders and top executives. To explain this phenomenon, public and scientific discussion has centered on the idea of a "glass ceiling" - a barrier of prejudice and discrimination that excludes women from higher level leadership positions (Federal Glass Ceiling Commission, 1995; Morrison, White, \& Van Velsor, 1987). To further this discussion, we advance a theory of prejudice toward female leaders and test the theory in relation to available empirical research. This integrative theory builds on social psychologists' tradition of studying prejudice and stereotyping and industrial-organizational psychologists' tradition of studying perceptions of managerial roles.

The popularity of the glass ceiling concept may stem from the rarity of women in major leadership posts, despite the presence of equality or near equality of the sexes on many other indicators. A number of statistics thus suggest equality: In the United States, women make up $46 \%$ of all workers (U.S. Bureau of Labor Statistics, 2001b) and $45 \%$ of those in executive, administrative, and managerial occupations (U.S. Bureau of Labor Statistics, 2001a); women possess $51 \%$ of bachelor's degrees and $45 \%$ of all

A draft of this article was written while Alice H. Eagly was a visiting scholar at the Murray Research Center of Radcliffe Institute for Advanced Study and supported by a sabbatical award from the James McKeen Cattell Fund. The writing of this article was also supported by National Science Foundation Grant SBR-9729449 to Alice H. Eagly. We thank Amanda Diekman, Judith Hall, Lauren Gibbs, Eric Hansen, Madeline Heilman, Mary Johannesen-Schmidt, Richard Martell, Tracie Stewart, Janet Swim, Marloes Van Engen, Claartje Vinkenburg, and Wendy Wood for comments on an earlier version of the article.

Correspondence concerning this article should be addressed to Alice $\mathrm{H}$. Eagly, Department of Psychology, Northwestern University, 2029 Sheridan Road, Swift Hall 313, Evanston, Illinois 60208, or to Steven J. Karau, Department of Management, Southern Illinois University, Carbondale, Illinois 62901-4627. E-mail: eagly@northwestern.edu or skarau@cba siu.edu advanced degrees (U.S. Bureau of the Census, 2000). In contrast, statistics pertaining to major leadership roles consistently show inequality: Women constitute $4 \%$ of the five highest earning officers in Fortune 500 companies and $0.4 \%$ of the CEOs (Catalyst, 2000); $13 \%$ of senators, $14 \%$ of congressional representatives, and $10 \%$ of state governors (Center for the American Woman and Politics, 2001); and 2\% of military officers at the level of brigadier general and rear admiral or higher (U.S. Department of Defense, 1998). Similarly small proportions of women in most high positions also characterize other industrialized and industrializing nations (Adler \& Izraeli, 1994; Melkas \& Anker, 1997).

Explanations for this sparse representation of women in elite leadership roles traditionally focused on the idea that a lack of qualified women created a "pipeline problem." This shortage of women has been ascribed to a variety of causes, including women's family responsibilities (Greenhaus \& Parasuraman, 1999) and inherited tendencies for women to display fewer of the traits and motivations that are necessary to attain and achieve success in high-level positions (e.g., Browne, 1999; S. Goldberg, 1993). However, because the convergence of the sexes on many humancapital variables raises questions about the sufficiency of such explanations, it is vital to evaluate whether prejudice is one of the causes of women's rarity in major leadership positions. To this end, we propose a role congruity theory of prejudice toward female leaders that (a) extends Eagly's (1987; Eagly, Wood, \& Diekman, 2000) social role theory of sex differences and similarities into new territory; (b) proposes novel, testable predictions about prejudice and its consequences; and (c) yields an effective organizing framework for a very large number of empirical findings from laboratories, field settings, organizations, and public opinion polls. In this article, we first explain the theory in general terms, then elaborate it by explaining the moderating conditions that allow it to make detailed predictions, and finally review empirical literature relevant to the theory.

\section{Role Congruity Theory: How Gender Roles and Leader Roles Produce Two Types of Prejudice}

In general, prejudice can arise from the relations that people perceive between the characteristics of members of a social group 
and the requirements of the social roles that group members occupy or aspire to occupy (Eagly, in press). A potential for prejudice exists when social perceivers hold a stereotype about a social group that is incongruent with the attributes that are thought to be required for success in certain classes of social roles. When a stereotyped group member and an incongruent social role become joined in the mind of the perceiver, this inconsistency lowers the evaluation of the group member as an actual or potential occupant of the role. In general, prejudice toward female leaders follows from the incongruity that many people perceive between the characteristics of women and the requirements of leader roles. To introduce this theory, we first explain how gender roles represent consensual beliefs about men and women, then consider the typical degree of congruity between the female gender role and leader roles, and finally present the two forms of prejudice that follow from this analysis.

\section{Gender Roles: Expectations About the Actual and Ideal Behavior of Women and Men}

To represent people's beliefs about women and men, our theory invokes the construct of gender role. Because social roles are socially shared expectations that apply to persons who occupy a certain social position or are members of a particular social category (Biddle, 1979; Sarbin \& Allen, 1968), gender roles are consensual beliefs about the attributes of women and men. As Eagly (1987) noted in her initial presentation of social role theory, "These beliefs are more than beliefs about the attributes of women and men: Many of these expectations are normative in the sense that they describe qualities or behavioral tendencies believed to be desirable for each sex" (p. 13). Thus, important in social role theory is that idea that roles include two kinds of expectations, or norms. To adopt Cialdini and Trost's (1998) terms, roles thus include descriptive norms, which are consensual expectations about what members of a group actually do, and injunctive norms, which are consensual expectations about what a group of people ought to do or ideally would do. Although the descriptive norms are thus synonymous with psychologists' usual definitions of stereotypes of group members, injunctive norms add a prescriptive element not traditionally included in the stereotype construct. The term gender role thus refers to the collection of both descriptive and injunctive expectations associated with women and men. ${ }^{1}$

According to social role theory, perceivers infer that there is correspondence between the types of actions people engage in and their inner dispositions. The descriptive aspect of gender roles thus originates in perceivers' correspondent inferences from the observed behavior of men and women to their personal qualitiesthat is, from the activities that men and women commonly perform in their typical social roles to the personal qualities that are apparently required to undertake these activities (Eagly, 1987; Eagly et al., 2000). Gender stereotypes thus follow from observations of people in sex-typical social roles-especially, men's occupancy of breadwinner and higher status roles and women's occupancy of homemaker and lower status roles (see Eagly et al., 2000).

Both the descriptive and injunctive aspects of gender roles are well documented. Evidence that descriptive norms-or stereotypes - are associated with women and men is abundant: People believe that each sex has typical—and divergent-traits and be- haviors (e.g., Broverman, Vogel, Broverman, Clarkson, \& Rosenkrantz, 1972; Diekman \& Eagly, 2000; Newport, 2001; J. E. Williams \& Best, 1990a). A key proposition of social role theory is that the majority of these beliefs about the sexes pertain to communal and agentic attributes (Bakan, 1966; Eagly, 1987). Communal characteristics, which are ascribed more strongly to women, describe primarily a concern with the welfare of other people-for example, affectionate, helpful, kind, sympathetic, interpersonally sensitive, nurturant, and gentle. In contrast, agentic characteristics, which are ascribed more strongly to men, describe primarily an assertive, controlling, and confident tendency-for example, aggressive, ambitious, dominant, forceful, independent, self-sufficient, self-confident, and prone to act as a leader. Although other types of attributes are also differentially ascribed to women and men (Deaux \& Lewis, 1983, 1984; Eckes, 1994), it is these communal and agentic attributes that especially illuminate the issues of prejudice that we discuss in this article.

Evidence abounds that gender roles also embrace injunctive norms about male and female behavior. Specifically, the overall approval of communal qualities in women and agentic qualities in men has been demonstrated in research on (a) the beliefs that people hold about ideal women and men (e.g., Spence \& Helmreich, 1978; J. E. Williams \& Best, 1990b), (b) the beliefs that women and men hold about their ideal selves (W. Wood, Christensen, Hebl, \& Rothgerber, 1997), and (c) attitudes and prescriptive beliefs that people hold about the roles and responsibilities of women and men (e.g., Glick \& Fiske, 1996; Spence \& Helmreich, 1978). Moreover, J. A. Hall and Carter (1999) showed that as behaviors become more sex differentiated in actuality (as assessed by meta-analytic data), people judge them as increasingly appropriate for only one sex. It thus appears that people tend to think that women and men ought to differ, especially in those behaviors that are associated with larger sex differences.

Consistent with social role theory (Eagly, 1987; Eagly et al., 2000) and social-cognitive research (see S. T. Fiske, 1998), gender roles have pervasive effects. Not only is sex the personal characteristic that provides the strongest basis of categorizing people, even when compared with race, age, and occupation (A. P. Fiske, Haslam, \& Fiske, 1991; Stangor, Lynch, Duan, \& Glass, 1992; van Knippenberg, van Twuyver, \& Pepels, 1994), but also stereotypes about women and men are easily and automatically activated (Banaji \& Hardin, 1996; Banaji, Hardin, \& Rothman, 1993; Blair \& Banaji, 1996). In addition, encoding processes

\footnotetext{
${ }^{1}$ Consistent with social role theory (Eagly, 1987), other researchers have adopted the distinction between descriptive and injunctive aspects of gender roles and have used varying labels for this distinction, including descriptive stereotypes and prescriptive stereotypes (e.g., Burgess \& Borgida, 1999; S. T. Fiske \& Stevens, 1993) and gender stereotypes and gender ideology (e.g., Cota, Reid, \& Dion, 1991). Typical descriptive measures are positively correlated with typical prescriptive or injunctive measures (see Burgess \& Borgida, 1999). Although we too might have adopted the descriptive stereotype versus prescriptive stereotype terminology, we prefer role terminology because (a) most definitions of social role include injunctive (or prescriptive) beliefs, whereas most definitions of stereotype do not; (b) analyses of leadership have generally adopted role terminology by analyzing managerial and leader roles; and (c) role terminology promotes an understanding of organizational behavior because roles are the building blocks of organizations (D. Katz \& Kahn, 1978).
} 
advantage information that matches gender-stereotypical expectations (von Hippel, Sekaquaptewa, \& Vargas, 1995), and spontaneous tacit inferences fill in unspecified details of male and female social behavior to be consistent with these expectations (Dunning $\&$ Sherman, 1997). The activation of beliefs about women and men by gender-related cues thus influences people to perceive women as communal but not very agentic and men as agentic but not very communal. Perceivers are likely to correct for the effects of these expectations only under somewhat narrow circumstances that may require both awareness that such expectations have been activated and the intention or motivation to counter their influence (e.g., Blair \& Banaji, 1996; Devine, Monteith, Zuwerink, \& Elliot, 1991; Kunda \& Sinclair, 1999; Plant \& Devine, 1998).

\section{Congruity of Gender Roles and Leadership Roles}

Role congruity theory is grounded in social role theory's treatment of the content of gender roles and their importance in promoting sex differences in behavior (Eagly et al., 2000). However, role congruity theory reaches beyond social role theory to consider the congruity between gender roles and other roles, especially leadership roles, as well as to specify key factors and processes that influence congruity perceptions and their consequences for prejudice and prejudicial behaviors.

The potential for prejudice against female leaders that is inherent in the female gender role follows from its dissimilarity to the expectations that people typically have about leaders. Prejudice can arise when perceivers judge women as actual or potential occupants of leader roles because of inconsistency between the predominantly communal qualities that perceivers associate with women and the predominantly agentic qualities they believe are required to succeed as a leader. People thus tend to have dissimilar beliefs about leaders and women and similar beliefs about leaders and men. In Schein's (1973, 1975) early empirical demonstration of this masculine construal of leadership, male and female managers gave their impressions of either women, men, or successful middle managers. These respondents perceived successful middle managers as considerably more similar to men than women on a large number of mainly agentic characteristics such as competitive, self-confident, objective, aggressive, ambitious, and able to lead. Researchers have replicated Schein's $(1973,1975)$ findings, not only in the United States (e.g., Heilman, Block, Martell, \& Simon, 1989; Massengill \& di Marco, 1979) but also in the United Kingdom, Germany, Japan, China, and Singapore (J. Lee \& Hoon, 1993; Schein, 2001). Also, studies in which participants merely rated managers (Arkkelin \& Simmons, 1985; Powell \& Butterfield, 1979, 1984, 1989) or holders of political offices (Rosenwasser \& Dean, 1989) on agentic and communal characteristics have demonstrated similarly masculine construals of leadership.

Combining of gender roles and leader roles. Observing an individual as an occupant of a leader role would place expectations based on gender in competition with expectations based on leadership. The idea that gender roles would continue to have some influence is consistent with the general argument that these roles are consequential in organizational settings. For example, Gutek and Morasch (1982) argued that gender roles spill over into the workplace, and Ridgeway (1997) maintained that gender provides an "implicit, background identity" (p. 231) in the workplace. In agreement with these claims, formal tests of models of the integration of expectations from multiple roles supported a weighted averaging model, with weights responsive to the task relevance of the expectations (e.g., Berger, Norman, Balkwell, \& Smith, 1992; Hembroff, 1982). To the extent that weighted averaging describes this combinatorial process, the ease with which expectations come to mind-that is, their accessibility-should also affect weighting. Because frequently and recently activated constructs are more accessible in memory (Higgins, 1996) and gender roles are automatically activated by gender-related cues in virtually all situations, the high accessibility of expectations based on gender likely maintains their impact. Therefore, in thinking about female leaders, people would combine their largely divergent expectations about leaders and women, whereas in thinking about male leaders, people would combine highly redundant expectations.

Empirical evidence is consistent with the principle that perceivers blend the information associated with a gender role and a leader role. For example, in a 1972 Louis Harris national opinion poll (Mueller, 1986; Sapiro, 1983), respondents reported that female holders of political offices were especially suited for pursuing what could be regarded as the communal goals of public policy (e.g., dealing with children and family problems, assisting the poor, working for peace) and that male officeholders were especially suited for pursuing what could be regarded as the agentic goals of public policy (e.g., directing the military and handling big business, domestic rebellion, the economy, and foreign relations). Further research showed that participants' inferences about leaders' sex-typed communal and agentic attributes mediated these perceptions of the abilities of female and male political leaders (Huddy \& Terkildsen, 1993b). Similarly, Heilman and her colleagues demonstrated that male managers rated "women managers" as more agentic and less communal than "women in general" but not as close as "men managers" to a group identified as "successful middle managers" (Heilman, Block, \& Martell, 1995; Heilman et al., 1989; see also Martell, Parker, Emrich, \& Crawford, 1998).

Leader behavior as violating injunctive norms of the female gender role. Despite the likely influence of gender roles in organizational settings, clear evidence that a woman conforms to the requirements of the leader role that she occupies should to some extent restrain gender-stereotypical inferences about her. Consistent with this prediction, both male managers (Heilman et al., 1995) and graduate students in business (Dodge, Gilroy, \& Fenzel, 1995) perceived that female managers who were described as successful were almost as similar to successful managers in general as successful male managers were.

Paradoxically, perceiving a female manager or leader as very similar to her male counterpart may produce disadvantage. This disadvantage can arise from the injunctive norms associated with the female gender role. Because women who are effective leaders tend to violate standards for their gender when they manifest male-stereotypical, agentic attributes and fail to manifest femalestereotypical, communal attributes, they may be unfavorably evaluated for their gender role violation, at least by those who endorse traditional gender roles. This reaction reflects the general tendency 
for deviations from injunctive norms to elicit disapproval (Cialdini $\&$ Trost, 1998). ${ }^{2}$

A woman who fulfills a leader role may thus elicit negative reactions, even while she may also receive some positive evaluation for her fulfillment of this role. Some evidence of this mix of positive and negative evaluations emerged in Heilman et al.'s (1995) finding that, even when the researchers described female managers as successful, participants regarded these women as more hostile (e.g., more devious, quarrelsome, selfish, bitter) and less rational (i.e., less logical, objective, able to separate feelings from ideas) than successful male managers. This research coheres with informal evidence of ambivalence that is inherent in the epithets often applied to powerful women, such as dragon lady and Battle-Ax (Tannen, 1994). More specific examples of such labeling include (a) Dawn Steel, the first woman to head a major movie studio in Hollywood, who was known as "Steel Dawn" and "the Tank" (Weinraub, 1997) and (b) Margaret Thatcher, British prime minister, who was labeled not only as "Iron Lady" but also as "Her Malignancy" and "Attila the Hen" (Genovese, 1993). To the extent that a woman who fulfills a leader role elicits a mixture of positive and negative reactions - that is, an ambivalent reaction-storage of these reactions in memory could have a variety of effects. As attitude researchers have shown, ambivalence can produce less consistency in expressions of an attitude across time and situations and a propensity for reactions to polarize- that is, become very negative or even sometimes very positive-depending on the particulars of the judgment context (e.g., I. Katz, Wackenhut, \& Hass, 1986; see reviews by Eagly \& Chaiken, 1993, 1998). Contexts that elicit especially unfavorable evaluations of a female (but not a male) leader include receiving a negative evaluation from her or otherwise having one's ego threatened by her (Atwater, Carey, \& Waldman, in press; Kunda \& Sinclair, 1999; Sinclair \& Kunda, 2000).

\section{Two Forms of Prejudice Toward Female Leaders}

A distinctive feature of our theory is the proposition that prejudice toward female leaders and potential leaders takes two forms: (a) less favorable evaluation of women's (than men's) potential for leadership because leadership ability is more stereotypical of men than women and (b) less favorable evaluation of the actual leadership behavior of women than men because such behavior is perceived as less desirable in women than men. As we have explained, the first type of prejudice stems from the descriptive norms of gender roles - that is, the activation of descriptive beliefs about women's characteristics and the consequent ascription of female-stereotypical qualities to them, which are unlike the qualities expected and desired in leaders. The second type of prejudice stems from the injunctive norms of gender roles-that is, the activation of beliefs about how women ought to behave. If female leaders violate these prescriptive beliefs by fulfilling the agentic requirements of leader roles and failing to exhibit the communal, supportive behaviors preferred in women, they can be negatively evaluated for these violations, even while they may also receive some positive evaluation for their fulfillment of the leader role. Women leaders' choices are thus constrained by threats from two directions: Conforming to their gender role would produce a failure to meet the requirements of their leader role, and conform- ing to their leader role would produce a failure to meet the requirements of their gender role.

These two forms of prejudice would both be manifested in less favorable attitudes toward female than male leaders and potential leaders. In addition, these two forms of prejudice should produce (a) lesser access of women than men to leadership roles and (b) more obstacles for women to overcome in becoming successful in these roles. The lesser access would follow from the tendency to ascribe less leadership ability to women, and the obstacles to success could follow from this aspect of prejudice as well as from the preference that women not behave in ways that are typical of leaders. Key tests of our theory thus examine sex differences in terms of less positive attitudes toward female than male leaders, more difficulty for women than men in achieving leadership roles, and more difficulty for women than men in becoming effective in these roles.

Women would not always be targets of prejudice in relation to women in leadership roles, because various conditions would moderate these prejudices. Because the first form of prejudice toward female leaders follows from incongruity between the descriptive content of the female gender role and a leadership role, prejudice would be lessened or absent to the extent this incongruity is weak or absent. In addition, because the second form of prejudice follows from incongruity between a leader's behavior and the injunctive content of the female gender role, other moderators would affect this form of prejudice. Specifically, the more agentically a leader role is defined or the more completely women fulfill its agentic requirements, the more likely such women are to elicit unfavorable evaluation because their behavior deviates from the injunctive norms of the female gender role. In addition, the role incongruity principle allows for prejudice against male leaders, to the extent that there exist leader roles whose descriptive and injunctive content is predominantly feminine. Because leadership is generically masculine, such leader roles are rare, and ordinarily women but not men are vulnerable to role incongruity prejudice in relation to leadership. Yet, as we show below, this prejudice against female leaders is responsive to various features of the leader's situation and characteristics of the perceiver. Key tests of our theory thus examine the impact of theory-relevant moderating variables on attitudes toward female and male leaders as well as on women's and men's access to and success in leadership roles.

\section{Conditions That Moderate Role Incongruity Prejudice}

\section{First Form of Prejudice}

To be predictive in a wide range of situations, our role incongruity theory must take into account the variability that exists in how gender roles and leadership roles are defined. Because role definitions are affected by many contextual and dispositional factors, numerous variables should moderate the two forms of prejudice that we have postulated. We first consider variables that affect the first form of prejudice — that is, regarding women as less

\footnotetext{
${ }^{2}$ In addition, negativity could follow from judging each sex's agentic qualities in relation to a within-sex standard, which would be lower for women than men (Biernat, 1995). A given agentic behavior delivered by a woman could thus be less positively evaluated because its greater subjective extremity makes it seem excessive.
} 
qualified than men for leadership. These several moderators can be understood in terms of the single principle that we have notednamely, that the greater the incongruity between the descriptive norms that define the female gender role and a leader role, the more likely that women are perceived as less qualified for leadership.

Masculinity of leader role. Variability in defining leader roles is a major influence on the amount of incongruity between the female gender role and leader roles. Although people ascribe predominantly masculine attributes to the generic leader role (see Bass, 1990; Heilman, 1983, 1995; Kruse \& Wintermantel, 1986; Martin, 1992; Nieva \& Gutek, 1980, 1981; Ragins \& Sundstrom, 1989; Schein, 2001), there is considerable variation in definitions of these roles. Therefore, greater incongruity follows from defining leader roles in particularly masculine terms-that is, in terms of qualities that are more agentic and less communal. To the extent that leader roles are less masculine, they would be more congruent with the female gender role, and therefore the tendency to view women as less qualified than men should weaken or even disappear. Moreover, more masculine definitions of leadership roles would reduce the likelihood that perceivers would spontaneously categorize women as leaders or potential leaders. Yet, such categorization would advantage person information that is consistent with leadership as demonstrated by Phillips and Lord (1982) and Kenney, Schwartz-Kenney, and Blascovich (1996). Men could thus experience a double advantage over women in perceived leadership ability — one increment from activating the male gender role, with its complement of agentic qualities, and a second increment from being categorized as a leader or potential leader and thereby gaining the agentic qualities associated with leadership.

It is important to consider the specifics of how leadership roles are defined because research has found that such role definitions vary widely across leadership domains, such as military, educational, health care, business, and political (Lord, Foti, \& de Vader, 1984; Lord \& Maher, 1993). Another determinant is the functional area of management within organizations, such as production, marketing, and personnel (Gomez-Mejia, McCann, \& Page, 1985). Especially relevant to the masculinity versus femininity of leader roles is the level of these roles in organizational hierarchies (Hunt, Boal, \& Sorenson, 1990; Lord \& Maher, 1993). To examine this variable, researchers have asked managers at differing levels to rate the importance of various abilities or activities for their jobs (e.g., Alexander, 1979; Gomez-Mejia et al., 1985; Paolillo, 1981; Pavett \& Lau, 1983). At the lower level, managers favored abilities involved in direct supervision such as leading, monitoring potential problems, and managing conflict. At the middle level, managers reported that their jobs demanded greater human relations skills that involve fostering cooperative effort and motivating and developing subordinates. At the executive level, managers believed that their jobs required a greater range of skills and activities, including monitoring information, serving as a liaison, manifesting entrepreneurial ability, and engaging in long-range planning. Also, a study of male managers' perceptions of the characteristics of successful executives yielded a set of highly agentic qualitiesspecifically, the ability to act as a change agent (e.g., inspirational, decisive), managerial courage (e.g., courageous, resilient), results orientation (e.g., action oriented, proactive), and leadership (e.g., leader, strategic thinker; Martell et al., 1998). Corroborating this association between higher level leadership and agentic qualities is a study of the attributes that people ascribe to political officeholders (Huddy \& Terkildsen, 1993a; see also Mueller, 1986). Although agentic characteristics were perceived to be more important than communal characteristics for all officeholders, agentic characteristics became even more important for higher level offices. In short, the incongruity between the female gender role and leader roles is likely to be most extreme at the highest levels of leadership. Yet, such incongruity might be somewhat lower for middle managers than for first level, or "line" managers, given the more socially complex elements of middle management activity.

In principle, extent of role incongruity could vary in response to differing definitions of gender roles as well as leader roles. However, essentially similar descriptive beliefs about the communal and agentic qualities of the sexes are apparently held by men and women, students and older adults, people who differ in social class and income, and citizens of many nations (e.g., Broverman et al., 1972; Jackman, 1994; Survey Research Consultants International, 1998; J. E. Williams \& Best, 1990a). Research thus suggests more constancy in the stereotypes that people hold about women and men than the stereotypes they hold about leaders.

Sex of perceivers. Individual differences in social perceivers may also influence the incongruity between leader and gender roles. One such variable is perceivers' sex, in view of evidence that men often have a more masculine construal of leadership than do women. Evidence of this construal emerges mainly from studies on perceptions of the managerial role similar to those by Schein (1973, 1975). According to Schein's (2001) review of this research, these newer studies have shown that in the United States, but not in several other nations (the United Kingdom, Germany, Japan, China), women, compared with men, generally have a more androgynous view of managerial roles as requiring communal qualities as well as agentic ones.

This difference between men's and women's perceptions of managers likely reflects the considerably greater experience of women with female managers. Even beyond the tendency of male and female managers to be clustered in different managerial occupations and functional specialities within organizations (U.S. Bureau of Labor Statistics, 2001a), men are far less likely than women to have a female manager (Reskin \& Ross, 1995). Because of their lesser experience with female managers, men would be less likely to imbue the social category with androgynous meaning. As a consequence of their more masculine perception of leadership, male perceivers should show a stronger tendency than female perceivers to view women as less qualified than men for leadership. Another mechanism that may enhance the tendency for men to view women as less qualified for leadership derives from men's greater social power, which can enhance their tendency to use gender-stereotypical information rather than available individuating information (Goodwin, Operario, \& Fiske, 1998).

Other moderators. Other likely influences on the perceived incongruity between the female role and leader roles include cultural milieus. Although the association of women with communal characteristics and men with agentic characteristics for the most part has generalized across nations (e.g., J. E. Williams \& Best, 1990a; J. E. Williams, Satterwhite, \& Best, 1999), cultural and subcultural variation warrants further exploration. For example, leader roles and the female gender role may be more consistent in the African American community than the European American community as Parker and Ogilvie (1996) argued. Change in role 
definitions over time remains a possibility as well, although there is little evidence that the descriptive content of the female and male gender roles has changed the past few decades, at least among American college students (e.g., Lueptow, Garovich, \& Lueptow, 1995; Spence \& Buckner, 2000). However, to the extent that leader roles become more androgynous (see the Conclusion section), the tendency to perceive women as less qualified than men should lessen.

Other interactions would follow from factors that increase the weight given to the female gender role, as opposed to the leader role, when perceivers combine the descriptive content of the two roles. In particular, certain feminine personal characteristics (e.g., pregnancy, feminine dress and grooming) might increase the accessibility of the female gender role and consequently make women seem particularly unqualified for leadership, compared with their male counterparts. Sex ratios should also produce interactions, because people who are in a small minority in a group on the basis of their sex attract more attention and in general are perceived more stereotypically (Kanter, 1977; Taylor \& Fiske, 1978). Given that women are increasingly in a minority position as they rise in organizational hierarchies, their female-stereotypical qualities become more salient, and the resulting perception of them in terms of these qualities produces disadvantage (Reskin, McBrier, \& Kmec, 1999; Yoder, 1991). Still other interactions may occur because people rely more on stereotypical beliefs when their cognitive resources are limited-for example, when they are under time pressure (e.g., Kruglanski \& Freund, 1983) or when they experience information overload (e.g., Macrae, Hewstone, \& Griffiths, 1993). The impact of gender roles may thus be enhanced when cognitive resources are reduced. In contrast, other conditions might decrease the weight assigned to gender roles relative to leader roles-for example, perceivers' own outcomes might be made dependent on accurate assessment of others' leadership ability (Rudman, 1998; Shackelford, Wood, \& Worchel, 1996).

\section{Second Form of Prejudice}

Other moderating conditions affect the second form of prejudice, which takes the form of evaluating the behavior of women who occupy leadership roles less favorably than the equivalent behavior of men-a reaction that follows from the injunctive aspects of the female gender role. Some of these moderators reflect the following general principle: The more agentically a leader role is defined or the more completely women fulfill its agentic requirements, the more likely such women are to elicit unfavorable evaluation because their behavior deviates from the injunctive norms of the female gender role.

Deviation from prescriptions about desirable female behavior would be greater to the extent that the leader role that women fulfill has a particularly agentic definition-as military officer roles do, for example. Also affecting a female leader's perceived deviation from the qualities preferred in women is the agentic style of her own behavior: To the extent that women fulfill their leader roles in a particularly dominant, assertive, directive, or selfpromoting style, they present greater deviation from the injunctive norms of the female gender role and would receive less positive reactions. In addition, adding communal features to leadership behavior, even though these are not required by the leader role, could allow women leaders to fulfill aspects of the female role.
They may thereby receive more positive reactions if they include in their repertoire some behaviors that are expressive, friendly, and participative, as long as these are not viewed as inappropriate for their leader role.

Finally, another moderator increasing the perceived deviation of female leaders from the injunctive norms of the female gender role and thereby increasing negative evaluation of them is perceivers' personal endorsement of these norms - that is, their approval of traditional gender arrangements or disapproval of nontraditional arrangements. Researchers have had considerable success in producing measures of individual differences in approval of traditional gender roles (e.g., Glick \& Fiske, 1996; Spence \& Helmreich, 1978). Approval of the traditional female gender role also varies according to (a) sex of perceiver, with men showing more approval (e.g., Glick \& Fiske, 1996); (b) year of data collection, with a decline over time in approval (e.g., Spence \& Hahn, 1997; Twenge, 1997); and (c) culture, with citizens of some nations showing more approval (e.g., Best \& Williams, 1993; Glick \& Fiske, 2001).

In summary, the perception of incongruity between leadership roles and the female gender role often results in prejudice toward female leaders. This incongruity arises because social perceivers typically construe leadership roles in agentic terms, whereas they expect and prefer that women exhibit communal characteristics. Yet, the degree of perceived incongruity between a leader role and the female gender role would depend on many factors, including the definition of the leader role, the weight given to the female gender role, and personal approval of traditional definitions of gender roles.

\section{Relevance of Other Theories of Gender Prejudice}

The role congruity theory of prejudice contrasts very sharply with classic theories that view prejudice as arising from holding an unfavorable stereotype and consequently a negative attitude toward a social group (e.g., Allport, 1954; Esses, Haddock, \& Zanna, 1993). From that perspective, women's underrepresentation as leaders would be ascribed to a negative stereotype and attitude toward women in general. However, such a context-free theory could not explain why women are discriminated against in some roles but not in others. Moreover, research on evaluations of women and men as social groups challenges this approach with evidence that women are not regarded as less good than men, even though they are perceived as inferior to men in power and status (see Eagly \& Mladinic, 1994; Langford \& MacKinnon, 2000; J. E. Williams \& Best, 1990a). In fact, in many recent studies, women have been evaluated somewhat more favorably than men, even in investigations using implicit attitudinal measures that assess the strength of association between male and female category labels and evaluative words (Carpenter, 2001). This perceived goodness of women appears to derive mainly from the communal aspects of the female gender role. Therefore, biases toward female leaders cannot result from the mere extension of a generalized negative attitude toward women.

Departing from traditional ideas about prejudice toward women, Glick and Fiske (1996, 2001) developed a theory of ambivalent sexism that encompasses both positivity and negativity toward women. These researchers maintained that prejudice toward women encompasses approval of women in traditional roles, la- 
beled benevolent sexism, and hostility toward women in nontraditional roles, labeled hostile sexism. These two forms of prejudice do not correspond to the two forms that we propose. Instead, they both elaborate the injunctive aspects of role incongruity prejudice by noting that incongruity elicits negative (or hostile) reactions, whereas congruity elicits positive (or benevolent) reactions. Thus, women occupying incongruent-or nontraditional-roles receive relatively negative reactions, whereas women occupying congruent-or traditional-roles receive more positive reactions. Glick and Fiske (1996) considered both types of reactions to be sexist.

More related to our role congruity theory of prejudice toward female leaders is Heilman's (1983) lack-of-fit model of bias in work settings. Heilman (1983) proposed that, to the extent that a workplace role is inconsistent with the attributes ascribed to an individual, she or he would suffer from perceived lack of fit to the workplace role, producing decreased performance expectations, increased expectations of failure, and decreased expectations of success. These effects would lower self-evaluation and evaluation by others. Heilman (1983) further argued that gender stereotypes would affect the perception of individuals' attributes and produce lack of fit with workplace roles that are perceived to require attributes stereotypical of the other sex. This theory is an important predecessor of our own because we, like Heilman (1983) emphasize the descriptive content of gender roles. Moreover, Heilman (2001) added a recognition of the importance of the prescriptive content of gender stereotypes, in concert with other scholars who have noted that many of the beliefs held about women are descriptively and prescriptively incongruent with many workplace roles (e.g., Nieva \& Gutek, 1981). However, our theory transforms these insights into a systematic theory by joining social-cognitive research on stereotyping and prejudice and industrial-organizational research on management and leadership. This conceptual breadth of our theory also allows it to account for a wide range of moderating conditions in terms of common underlying mechanisms.

Burgess and Borgida (1999) proposed another related theory in the context of studying sexual harassment and discrimination. They argued that the "descriptive and prescriptive components of gender stereotypes" (p. 666) result in different types of workplace discrimination. Specifically, they held that descriptive stereotypes lead to discrimination that is labeled disparate impact, in which "institutional practices result in hiring and promotion decisions that are biased against a class of people" (p. 666), whereas prescriptive stereotypes lead to discrimination that is labeled disparate treatment, in which "women who violate prescriptive stereotypes of femininity are punished, either through hostile environment harassment or through the devaluation of their performance" (p. 666). Although this approach provides a welcome complement to our own theory in arguing for the potential of descriptive and injunctive gender roles to produce discrimination in workplace settings, the approach is not specifically tailored to provide an analysis of leadership.

\section{Examining Research Relevant to the Theory}

We now present research that has investigated the consequences of prejudice that are predicted by our role congruity theory. This research provides many opportunities to examine the general prejudicial effects that this theory predicts as well as the moderating conditions it proposes. These paradigms are organized according to whether they investigate (a) attitudes toward women and men as leaders, (b) the access of men and women to leadership roles, or (c) the success of women and men in leadership roles. The diversity of paradigms that we consider illustrates the power of the role congruity theory of prejudice to integrate research carried out by social and industrial-organizational psychologists, management specialists, political scientists, sociologists, and economists.

If we follow Allport's (1954, p. 9) rule that "The net effect of prejudice is to place the object of prejudice at some disadvantage not merited by his own conduct," only disadvantage not merited by group members' own behavior can be confidently labeled as prejudicial. Therefore, to take Allport's dictum into account, we show that these consequences of prejudice are intact in experimental research paradigms that equate the objective characteristics of male and female leaders other than their sex. Organizational studies and other field studies that do not equalize the behavior of the sexes can offer advantages of external validity, but such studies are vulnerable to the criticism that actual sex differences might account for apparently prejudicial reactions. For example, holding a less favorable attitude toward female than male leaders could follow from observed behavioral differences between them or from female leaders' tendency to occupy less powerful positions (Kanter, 1977). Also, in natural settings in which leaders' behavior is free to vary, any lesser access of women to leadership or lesser success in these roles could reflect the behavioral nonequivalence of the men and women who are compared. Therefore, whenever possible, we examine experiments that equated the attributes of men and women, but we also review field and correlational studies that did not provide this control.

\section{Do People Have a Less Favorable Attitude Toward Women Than Toward Men in Leader Roles?}

The two forms of prejudice that we postulated, stemming from the descriptive and injunctive aspects of the female gender role, should jointly produce less favorable attitudes toward female than male leaders and potential leaders, although this female disadvantage should have decreased over time. The Gallup Poll illustrates the attitudinal approach by asking respondents if they would prefer a male or female boss (Simmons, 2001b). The responses for selected years ranging from 1953 to 2000 appear in Table 1. Although this question once elicited greater preference for male bosses on the part of men than women, it recently yielded greater preference for male bosses on the part of women than men. Yet, women consistently indicated greater preference for female bosses than men did. This seeming paradox is explained by men's more sharply increasing tendency to volunteer that the sex of bosses makes no difference. Despite these complex trends, a strong preference for male bosses over female bosses was present for both sexes at all time points, and this preference was present in all 22 of the nations that Gallup surveyed in 1995 (Simmons, 2001b).

Researchers have developed scales to assess attitudes toward female managers. Most widely used is the Women As Managers Scale, developed by L. H. Peters, Terborg, and Taynor (1974), which contains items such as "It is not acceptable for women to assume leadership roles as often as men" and "Women are not ambitious enough to be successful in the business world." This measure and a similar instrument developed by Dubno, Costas, Cannon, Wanker, and Emin (1979) have shown less favorable 
Table 1

Responses by Men and Women in Selected Years to Gallup Poll's Question About Preferring a Man or Woman as Boss

\begin{tabular}{|c|c|c|c|c|c|}
\hline Response and sex of respondents & 1953 & 1975 & 1982 & 1995 & 2000 \\
\hline \multicolumn{6}{|l|}{ Man preferred as boss } \\
\hline Men & 75 & 63 & 40 & 37 & 45 \\
\hline Women & 57 & 60 & 52 & 54 & 50 \\
\hline Total & 66 & 62 & 46 & 46 & 48 \\
\hline \multicolumn{6}{|l|}{ Woman preferred as boss } \\
\hline Men & 2 & 4 & 9 & 17 & 19 \\
\hline Women & 8 & 10 & 15 & 22 & 26 \\
\hline Total & 5 & 7 & 12 & 20 & 22 \\
\hline \multicolumn{6}{|l|}{ Either sex or no difference (volunteered) } \\
\hline Men & 21 & 32 & 46 & 44 & 35 \\
\hline Women & 29 & 27 & 30 & 24 & 22 \\
\hline Total & 25 & 29 & 38 & 33 & 28 \\
\hline
\end{tabular}

Note. Data are reported in percentages of respondents giving each of the indicated responses to the question, "If you were taking a new job and had your choice of a boss, would you prefer to work for a man or a woman?" (Simmons, 2001b). Numbers do not add up to 100 because "no opinion" is not shown.

attitudes toward managerial women among men than women in samples of employees (Terborg, Peters, Ilgen, \& Smith, 1977; Tomkiewicz \& Adeyemi-Bello, 1995) and students (Dubno, 1985; Dubno et al., 1979) but some favorable change among men between 1975 and 1987 (Russ \& McNeilly, 1988).

The Harvard Business Review twice published surveys of the attitudes of large samples of male and female executives (Bowman, Worthy, \& Greyser, 1965; Sutton \& Moore, 1985). Among the items administered in both surveys was the general question, "Overall, would you say your own basic attitude toward women in management is: strongly favorable, mildly favorable, indifferent, mildly unfavorable, or strongly unfavorable?" Choosing the strongly or mildly favorable responses were $35 \%$ of the men and $82 \%$ of the women in 1965 , compared with $73 \%$ of the men and $91 \%$ of the women in 1985 . The general conclusion from these surveys was that in 1965 the majority of male executives, but not female executives, disapproved of women in executive roles and that by 1985 , this bias against women on the part of male executives had abated considerably but not disappeared.

Several items administered in the General Social Survey, a nationally representative U.S. survey, are informative about attitudes toward women and men as political leaders (see Table 2 for items). These data show some overall intolerance of women compared with men in political roles, increasing tolerance for women between 1974 and 1998, and few differences between male and female respondents. The question about voting for a qualified woman for president was also included in Gallup polls between 1958 and 1972 (see Ferree, 1974). Like the later surveys, these earlier surveys yielded gradually increasing willingness to vote for a female presidential candidate of one's own party, moving from approval by only $54 \%$ in 1958 to $69 \%$ in 1972 . In response to a 1999 Gallup Poll question concerning whether a woman or man would make a better president, everything else being equal, $42 \%$ of respondents favored a man, $31 \%$ favored a woman, and $22 \%$

Table 2

Responses by Men and Women in Selected Years to General Social Survey Items Pertaining to Political Leadership

\begin{tabular}{|c|c|c|c|c|c|c|c|}
\hline Item and sex of respondent & 1974 & 1978 & 1982 & 1985 & 1990 & 1994 & 1998 \\
\hline \multicolumn{8}{|c|}{$\begin{array}{l}\text { Agreement with "Women should take care of running their } \\
\text { homes and leave running the country up to men" }\end{array}$} \\
\hline Men & 36 & 31 & 30 & 25 & 18 & 15 & 15 \\
\hline Women & 35 & 32 & 27 & 27 & 18 & 14 & 16 \\
\hline Total & 36 & 32 & 28 & 26 & 18 & 14 & 15 \\
\hline \multicolumn{8}{|c|}{$\begin{array}{l}\text { Agreement with "Most men are better suited emotionally for } \\
\text { politics than are most women" }\end{array}$} \\
\hline Men & 48 & 41 & 39 & 38 & 28 & 22 & 21 \\
\hline Women & 47 & 46 & 36 & 39 & 26 & 20 & 22 \\
\hline Total & 47 & 44 & 38 & 39 & 27 & 21 & 22 \\
\hline \multicolumn{8}{|c|}{$\begin{array}{l}\text { Yes response to "If your party nominated a woman for president, } \\
\text { would you vote for her if she were qualified for the job?" }\end{array}$} \\
\hline Men & 81 & 83 & 86 & 85 & 90 & 92 & 91 \\
\hline Women & 80 & 80 & 86 & 80 & 89 & 92 & 90 \\
\hline Total & 80 & 82 & 86 & 82 & 89 & 92 & 90 \\
\hline
\end{tabular}

Note. Data are reported in percentages of respondents (National Opinion Research Center, 1998). 
indicated that the sex of the president would not matter; on this question, women were more likely than men to favor a woman$39 \%$ versus $22 \%$ (Simmons, 2001a).

Opinion polls can suffer from contamination by respondents' self-presentational concerns, especially to the extent that they believe that indicating a preference for one sex might reveal prejudice. Studies oriented to circumventing this problem have applied implicit measurement techniques to examine attitudes toward female and male leaders. Using the Implicit Association Test (Greenwald, McGhee, \& Schwartz, 1998), Carpenter (2001) assessed the strength of student participants' associations between the terms male leaders and female leaders (and in one experiment the names of actual male and female leaders) and pleasant and unpleasant evaluative words (e.g., laughter, excellent, cancer, terrible). The results of her several experiments suggested that the women had a more favorable implicit attitude toward female than male leaders, whereas men's attitudes were inconsistent across the experiments (i.e., more positive toward male leaders, toward female leaders, or equal evaluation of male and female leaders). Using a different type of implicit measure involving priming (see Fazio, Jackson, Dunton, \& Williams, 1995), Rudman and Kilianski (2000) primed student participants with schematic drawings of male or female authority figures (e.g., doctor, boss, judge) and assessed latency of response to positive or negative adjectives. This method suggested that both male and female students had negative attitudes toward female authority figures and more neutral attitudes toward male authority figures. However, women showed less prejudice than did men on an explicit measure on which respondents indicated their preferences for male versus female authorities. Reconciling the differences in findings from various implicit and explicit measurement paradigms awaits additional research.

In general, attitudinal data show some disapproval of female leaders, although on a decreasing basis and sometimes with more disapproval on the part of male respondents. Although it is not surprising that there are some inconsistencies in these findings, in view of the considerable diversity of measures and participant populations, they are supportive of the role congruity theory of prejudice. However, because factors other than prejudice could underlie less favorable attitudes toward female than male leaders (e.g., differing behavior on the part of female and male leaders), we turn to other research paradigms, some of which equate the objective characteristics of men and women.

\section{Do Women Have Less Access Than Men to Leadership Roles?}

One prediction following from our role congruity theory is that achieving leadership is more difficult for women than men, because of the common perception that women have less leadership ability and (often) the preference that women not exhibit this ability and instead engage in communal, supportive behavior. The plausibility of this proposition would be enhanced by evidence that women have less access than men to positions of power in natural settings as suggested by indicators such as wages and promotions. Providing another paradigm are experiments on reactions to hypothetical male and female job candidates whose characteristics have been equated. Also relevant is research on the perception of task competence and leadership ability and on the evaluation of agentic behavior. Studies of the emergence of leaders from initially leaderless groups are also informative. We review relevant evidence from each of these research paradigms.

\section{Studies of Actual Wages and Promotion}

Researchers have examined sex discrimination in wages and promotion to determine whether the returns for skills and job characteristics are greater for one sex than the other, once other determinants of wages are taken into account. Although these methods are generally accepted, they are vulnerable to omitting determinants of wages that may explain sex differentials and to including determinants that may be biased by prior sex discrimination. Despite these ambiguities, there is general agreement that such studies have demonstrated wage discrimination against women (e.g., Bergmann, 1989; Blau \& Ferber, 1987; Jacobsen, 1998). Although Stanley and Jarrell's (1998) meta-analysis of the results of 41 studies estimating wage discrimination showed an unequivocal decrease over time (see also Solberg, 1999), other detailed analyses confirm that some wage discrimination against women remains in the United States (Bayard, Hellerstein, Neumark, \& Troske, 1999).

The improvement of women's wages relative to those of men in recent years probably reflects several broader changes in labor market dynamics (e.g., the stagnation of men's wages due to economic restructuring and the globalization of industry; see Morris \& Western, 1999). In addition, potential causes consistent with the role congruity theory of prejudice include the lessening numerical tokenism of women in many management positions and the increasing power of women to make personnel decisions as owners of small businesses and as decision makers in larger organizations (see Reskin et al., 1999). For example, in the savings and loan industry the traditional tendency for women to hold positions at lower but not higher managerial levels decreased between 1975 and 1987 (Cohen, Broschak, \& Haveman, 1998). This study's results suggested the importance of sex ratios and women's role as decision makers-specifically, promotions of women into a higher job level were more likely to the extent that a higher proportion of women was already at that upper level (up to $50 \%$ ) as well as at the applicants' current job level.

Jacobs (1992) examined wages in a nationally representative sample of managers. Among these managers, the magnitude of the discriminatory wage gap favoring men exceeded the wage gap in the labor force as a whole, although this managerial gap decreased over time. Averaging across the sectors of the economy, female managers were given less authority and earned less than male managers, even when managerial level and tenure in organizations were controlled (Reskin \& Ross, 1995). Other studies showed that female managers, compared with their male counterparts at the same level, had less access to the high-level responsibilities and the complex challenges that are likely precursors to promotion (Lyness \& Thompson, 1997; Ohlott, Ruderman, \& McCauley, 1994). In addition, Olson and Frieze's (1987) narrative review of research on managers' incomes, including 12 studies of recipients of the masters of business administration (MBA) degree, found little evidence for a sex difference in starting salaries but evidence of a later wage gap favoring men that increased the longer that individuals were followed. This trend, which was typically explained only in part by human-capital variables, presumably re- 
flected men's faster ascent in organizational hierarchies. Subsequent studies confirmed these divergent career paths for female and male managers (e.g., Cox \& Harquail, 1991; Schneer \& Reitman, 1994; Stroh, Brett, \& Reilly, 1992) and lawyers (Kay \& Hagan, 1998; Spurr, 1990; R. G. Wood, Corcoran, \& Courant, 1993), and a study of managerial employees in a large financial services organization showed that, compared with men, women at higher levels of management were less likely to be promoted (Lyness \& Judiesch, 1999). Also, a study of the military suggested some male advantage in selection for key assignments, which consisted of opportunities to command and serve as executive officer and senior enlisted advisor (U.S. General Accounting Office, 1998). The quicker promotion of men into leadership positions is prevalent or even accentuated in female-dominated fields (e.g., Maume, 1999; Ott, 1989; C. L. Williams, 1992, 1995; Yoder $\&$ Sinnett, 1985). Findings that have been interpreted as demonstrating discrimination against women have thus emerged for a variety of types of leader roles.

In contrast to these studies suggesting discrimination, Powell and Butterfield (1994) found greater success for women than men in promotions in the Senior Executive Service of a cabinet-level government agency. Women were more qualified and retained a small advantage over men, even above and beyond their higher status on human-capital variables and performance evaluations. This study may have had this unusual outcome because of the federal government's commitment to affirmative action and its imposition of personnel procedures that may counter traditional biases (e.g., use of explicit criteria, requirement of extensive record keeping). Supporting the idea of less discrimination in governmental positions is evidence that the wage gap is generally smaller in the public sector than the private sector (Robinson, 1998).

In summary, in social scientific research, the lower wages and slower promotion that women experience in the labor force as a whole and in managerial occupations have typically been ascribed in part to sex discrimination, because of the difficulty in fully accounting for these differentials in terms of human-capital variables. Nonetheless, researchers have found less evidence of discrimination in the public sector compared with the private sector and substantial evidence of an overall decrease in discrimination over time. However, employment discrimination is not necessarily a product of employers' prejudices (see Jacobsen, 1998), and it is difficult for researchers to evaluate the impact of aspects of female choice (e.g., women setting priorities to achieve greater workfamily balance; see Townsend, 1996). Therefore, we proceed to examine research in paradigms that can reflect prejudice more directly.

\section{Goldberg-Paradigm Experiments on Hiring Hypothetical Candidates}

A research paradigm targeted to testing whether women suffer disadvantage relative to equivalent men consists of experiments in which participants evaluate men and women whose characteristics have been equated. This method of examining potential bias against women has been labeled the Goldberg paradigm in honor of P. Goldberg's (1968) initial experiment, in which identical articles ostensibly written by a woman or a man were given to students for evaluation. The experimental control used in such studies circumvents the ambiguities inherent in attempting to statistically control the attributes of the women and men who are compared - the method used in studies of actual wages and promotion.

Researchers quickly applied this unobtrusive method to studying discrimination in hiring and promotion, because the hallmarks of the experimental method-manipulation of the independent variable and random assignment of participants to the resulting conditions - allow a causal argument about the effects of the sex of the potential target of prejudice. Especially popular was the procedure of presenting a résumé or application for evaluation, with half of the participants receiving it with a female name attached to it and half receiving it with a male name (e.g., Rosen \& Jerdee, 1974). Narrative reviews of this literature (Arvey, 1979; Dipboye, 1987) were followed by meta-analyses (Olian, Schwab, \& Haberfeld, 1988; Swim, Borgida, Maruyama, \& Myers, 1989; Tosi \& Einbender, 1985). The most extensive meta-analysis of the subset of Goldberg studies presenting job résumés or applications was based on information in 49 articles and dissertations. The results showed that men were preferred over women for jobs rated as male sex-typed (mean $d=0.34$ ) and women over men for jobs rated as female sex-typed (mean $d=-0.26$; Davison \& Burke, 2000). Given that leadership roles are usually sex-typed as masculine, this research supports our theory's prediction of bias against female candidates for such positions.

Several experiments using hypothetical candidates for leadership positions are relevant to the role congruity theory principle that conditions increasing the weight given to the female gender role disadvantage women. For example, female job candidates' physical attractiveness should make the female gender role salient, given that attractive women are perceived more gender stereotypically than unattractive women (e.g., Lippa, 1998). Therefore, when applying for managerial positions, attractive women were evaluated less favorably than their unattractive counterparts, although they were evaluated more favorably when applying for nonmanagerial jobs (Heilman \& Saruwatari, 1979). Similarly, Cash, Gillen, and Burns (1977) found that a woman's beauty was a disadvantage in applying for male-dominated positions but an advantage in applying for female-dominated positions. However, these effects of physical attractiveness have sometimes not replicated (e.g., Bieber \& Dipboye, 1988; Dipboye, Arvey, \& Terpstra, 1977; Dipboye, Fromkin, \& Wiback, 1975), perhaps because diverse meanings are derived from differing types of attractiveness (Ashmore, Solomon, \& Longo, 1996; Green \& Ashmore, 1998). The idea that feminine clothing could also disadvantage women was tested by presenting videotaped interviews of women applying for managerial positions (Forsythe, Drake, \& Cox, 1985). These applicants' clothing was more feminine or masculine as conveyed by subtle differences in their skirted outfits. Femininity of dress decreased the favorability of the hiring recommendation. Yet, consistent with the role congruity theory prediction that women's complete conformity to the norms of a leader role elicits some negative evaluation, applicants in the most masculine costume, which most approximated male managers' typical costume (albeit with a skirt), were evaluated more negatively than applicants in the moderately masculine costume. Finally, in another experiment presenting female applicants for managerial positions, women fared less well as the proportion of women in the applicant pool decreased (Heilman, 1980); the perception of token women as 
more feminine apparently produced this disadvantage. In summary, physical attractiveness, feminine clothing, and token status illustrate variables that may disadvantage women because they cause perceivers to weight the female gender role more heavily when judging women leaders.

In this research literature, equalizing job candidates who differ by sex is achieved at the cost of presenting hypothetical candidates by means of a limited amount of information. Yet, in defense of the method, evaluating résumés is part of personnel selection in many organizations. Moreover, there is some evidence that studies using hypothetical applicants can effectively model the processes that occur in relation to actual applicants (Cleveland, 1991). In addition, several other features of these studies' methods and findings enhanced their likely generalizability. First, researchers frequently used managers or recruiters, not merely university students, as evaluators. Second, the magnitude of bias did not differ across these classes of evaluators when examined metaanalytically (Olian et al., 1988). Third, a number of more naturalistic but less controlled field experiments have been conducted in which job applications were sent to companies (Firth, 1982; McIntyre, Moberg, \& Posner, 1980) or applicants responded by telephone to advertised jobs (Levinson, 1982). These studies also showed discrimination that depended on the sex-typing of jobs. For example, in the Levinson study, male and female students responded to classified advertisements placed in two Atlanta newspapers for jobs that were male or female dominated. The majority of callers whose sex did not match the typical sex of jobholders elicited discriminatory responses. These responses included (a) outright refusals based on sex ("Honey, I'm sorry, but we need a man to do that"; Levinson, 1982, p. 57), (b) telling the sexmismatched caller that the job was filled and the matched caller that the job was open, and (c) skeptical and discouraging reactions (e.g., "It's hard to believe that a guy is really qualified for this work"; Levinson, 1982, p. 59).

Finally, another methodological consideration is the possible contaminating influence of Kasof's (1993) naming bias, which takes the form of researchers inadvertently choosing more positive names for male than female stimulus persons in Goldbergparadigm experiments. However, this bias should not have been a major source of invalidity in these résumé studies, because whether men or women were devalued varied, depending on the sex-typing of the job.

\section{Studies of Agentic Behavior by Men and Women}

In additional research paradigms, researchers have examined reactions to women's agentic behavior (see the review by Carli \& Eagly, 1999). Although the individuals whose behaviors were evaluated were not explicitly identified as leaders, they were typically engaging in behavior that is highly relevant to becoming a leader. Moreover, researchers' equating of male and female behavior in most of these experiments allows them to answer the question of whether agentic women suffer disadvantage relative to equivalent men as role congruity theory maintains.

Double standard in ascribing agentic attributes. According to the role congruity theory of prejudice, the application of the female stereotype to women, with its lower level of agency, should decrease a woman's chances of being perceived as possessing agentic attributes. Therefore, it is relevant to examine experiments on the ascription of these attributes to men and women in taskoriented groups, which are typically laboratory groups with student participants. In general, this research shows that it is easier for men to be perceived as possessing the task-relevant competence and leadership ability that are essential to emerging as a leader.

To the extent that women are assimilated to the relative lack of agency inherent in the norms of the female gender role, a double standard would exist about task competence, so that women must perform better than men to be considered very competent. In the context of status characteristics theory (see Berger, Webster, Ridgeway, \& Rosenholtz, 1986), evidence that perceivers use different standards to evaluate male and female behavior has been produced in experiments that equated the behavior of the men and women with whom participants interacted (e.g., Foschi, 1996; Foschi, Lai, \& Sigerson, 1994; see review by Foschi, 2000). In general in such demonstrations, participants perceived men as more competent and were more influenced by them. This shift to higher standards for inferring women's ability occurred even when women judged themselves. However, despite requiring more evidence from women than men to infer high ability, people set lower standards for women for the amount of task competence that they considered minimally acceptable (Biernat \& Kobrynowicz, 1997), an effect that presumably reflects belief in women's lesser competence. Yet, in order to be perceived as competent to lead a group or organization, a person must be perceived as highly able, and therefore women are disadvantaged by the double standard. In an important field study showing just such an effect, Biernat, Crandall, Young, Kobrynowicz, and Halpin (1998) examined group members' judgments of their own and others' leadership ability among U.S. Army captains attending a leadership training course. Controlling for a variety of status factors that included indicators of merit and years at the rank of captain, these researchers found a bias in favor of men that was evident both in judgments of others' leadership ability and in self-judgments, particularly for women in a solo or token situation in their groups. This evidence coheres with managerial women's reports of intense performance pressures, especially if they are in a token situation (Kanter, 1977).

In accord with the role congruity theory of prejudice, muting the double standard requires clear and explicit evidence of women's high level of competence (Foddy \& Smithson, 1999; Heilman, Martell, \& Simon, 1988; Pugh \& Wahrman, 1983; Shackelford et al., 1996; Wagner, Ford, \& Ford, 1986; W. Wood \& Karten, 1986). In fact, such evidence can produce circumstances in which women's task competence can be overvalued. Given very convincing evidence of a woman's competence in a situation that would seem to be extremely unfavorable to her because of its strongly masculine definition, perceivers may view her performance as even more competent than that of an equivalent man (e.g., Abramson, Goldberg, Greenberg, \& Abramson, 1977; Heilman et al., 1988; Taynor $\&$ Deaux, 1973). This effect presumably occurs because perceivers augment the causal importance of a force (i.e., task competence) that they believe has prevailed over a countervailing force (i.e., discrimination; Kelley, 1972).

Less favorable evaluation of women's (than men's) agentic behavior. Even if a woman does achieve recognition for her competence, this recognition may not have the same potential for producing leadership that it would for a man, because of the impact of the second form of prejudice postulated by the role congruity theory of prejudice-that is, less approval of agentic behavior 
enacted by a woman compared with a man. Research has shown that in groups containing both sexes the relation of competent task contributions to gaining influence is stronger for men than for women (Walker, Ilardi, McMahon, \& Fennell, 1996). In general, the competent task contributions of women are more likely to be ignored or to evoke negative reactions than those of men (Altemeyer \& Jones, 1974; Ridgeway, 1978, 1981, 1982). Also, women who genuinely exert influence are less likely to be liked or recognized as influential than men who exert influence (Butler \& Geis, 1990; Walker et al., 1996).

Leaders are expected not only to be competent but also to be appropriately confident and assertive. Therefore, behaving in this manner should help an individual gain influence and become a leader. However, a number of experiments have shown that achieving influence in this manner is more difficult for women than men, particularly when they deal with men. Reactions to assertive, confident women reflect the evaluative bias that our role congruity theory postulates is directed toward women whose actions approximate the agentic behavior expected of leaders and do not match the communal behavior expected of women.

Illustrating these phenomena are Carli's (1990) studies of tentativeness in speech, as conveyed by tag questions, hedges, and disclaimers. For a male audience, tentative women were more influential and perceived as more trustworthy than confident women, whereas men's tentativeness did not affect reactions to them. However, for a female audience, confident speakers were more influential than tentative speakers, regardless of their sex. Men but not women thus resisted the influence of confident, assertive women. Also, Wiley and Eskilson (1985) found that male students liked a female applicant for a managerial position better if she spoke tentatively, whereas female students liked her better if she spoke confidently. Liking of male applicants was unaffected by their style of speech. Furthermore, another aspect of agentic behavioral style that is ordinarily associated with high social power is visual dominance, a tendency to look at an interaction partner while speaking more than while listening (e.g., Dovidio, Ellyson, Keating, Heltman, \& Brown, 1988). In mixed-sex interactions, visual dominance by men but not women was associated with effective influence (Mehta, Dovidio, Gibbs, Miller, Huray, Ellyson, \& Brown, 1989, as cited in Ellyson, Dovidio, \& Brown, 1992). ${ }^{3}$

Self-promoting behavior, which makes one's competence visible, is another important part of the agentic repertoire. Selfpromotion generally enhances the extent to which a person is perceived as competent (Jones \& Pittman, 1982) and increases a person's attractiveness as a job candidate (Stevens \& Kristof, 1995). Yet, in public but not private self-presentations, women are particularly modest about their successes (Daubman, Heatherington, \& Ahn, 1992; Heatherington et al., 1993). This modesty is understandable, given that self-promotion, which produces positive outcomes for men, is relatively unsuccessful for women (Giacolone \& Riordan, 1990; Wosinska, Dabul, Whetstone-Dion, \& Cialdini, 1996). Showing some of the difficulties that women can experience from self-promotion, Rudman (1998) conducted experiments examining a variety of reactions to men and women who described themselves in either a self-promoting or self-effacing manner. This research showed that self-promotion in the form of speaking directly and highlighting one's accomplishments can make a woman less likable, attractive, and hireable as a partner for a competitive game, whereas self-promoting men do not suffer these costs. In contrast to the typical tendency for men to react more negatively than women to women's agentic behavior, Rudman found that under some circumstances the disapproval of self-promoting women was stronger among the female participants.

There appear to be conditions that increase the likelihood that confident, competent women become effective and influential. In addition to the obvious method of making women's abilities especially outstanding and presenting this information prominently (e.g., Eskilson \& Wiley, 1976; Shackelford et al., 1996), another method involves reducing bias against women by making group members' own success depend on accurate assessment of one another's ability (Rudman, 1998; Shackelford et al., 1996).

A different method of enhancing women's success with an agentic repertoire consists of complementing it with communal behaviors (e.g., Shackelford et al., 1996; Watson, 1988). According to our role congruity theory, prejudice lessens because such behavior reduces agentic women's overall disparity from the female gender role. Illustrating these positive effects of communal behavior for women, Ridgeway (1982) showed that female confederates who attempted to exert influence in a group of men were considerably more successful if they adopted a style that was friendly, considerate, and supportive rather than more emotionally distant and self-confident. However, this communal style did not confer this substantial advantage on male confederates or female confederates in a group of women. Also, examining agreement with others as communal behavior, Carli (1998) paired each male or female participant with a male or female confederate who exhibited agreement or disagreement in the interaction. Although male confederates were equally influential and likable whether they had previously agreed or disagreed with participants, female confederates were more influential and likable when they had agreed. Finally, Carli, LaFleur, and Loeber (1995) had male and female students view a videotape of a male or female speaker delivering a persuasive message while displaying various nonverbal styles. Sex-of-participant differences emerged in response to the competent, task-oriented style, which lacked any special nonverbal warmth and friendliness. In response to this style, male participants were less influenced by the female speakers than the male speakers and judged these female speakers to be less likable and more threatening than their male counterparts. In contrast, female participants were equally influenced by these male and female speakers. Also, male participants liked more and were more influenced by competent female speakers when these women combined their competent style with warmth and friendliness (e.g., friendly facial expression, forward body leaning). Women thus lost influence with men if they used a competent style that was not leavened by a substantial amount of nonverbal warmth. In general, the less favorable reactions more often directed toward women's than men's assertive, leaderlike behavior can be mitigated to some

\footnotetext{
${ }^{3}$ In an apparent exception to these findings, Aguinis and Adams (1998) found that evaluations of managers displaying direct, assertive influence behavior versus indirect, passive influence behavior were unaffected by the sex of the manager. The implications of these findings are ambiguous, however, given that the managerial role (customer service manager) may have been relatively feminine and the videotaped stimuli used only one male and one female actor.
} 
extent by the addition of interpersonally facilitative behaviors consistent with the female gender role.

Considerable experimental evidence thus supports the role congruity theory prediction that women often receive less favorable reactions to their agentic behavior than men do, unless other conditions are present-for example, presenting very convincing evidence of ability or complementing agentic behavior with at least certain types of communal behavior. According to our theory of prejudice, these negative reactions to women's agency reflect the injunctive norms of the female gender role by which women ought to be communal but not very agentic.

\section{Studies of the Emergence of Leaders}

Studies of leader emergence in task-oriented groups also yield understanding of whether men are advantaged in becoming leaders. Most such studies are laboratory experiments in which small groups of students discussed a particular topic or solved problems (e.g., Nemeth, Endicott, \& Wachtler, 1976). In the typical study, researchers assessed leadership by obtaining group members' responses to questionnaire measures of leadership contribution or by coding members' verbal behavior. Other, more naturalistic studies of emergent leadership examined initially leaderless groups composed of students from a university course who generally met for most of a semester to work on projects (e.g., Schneier \& Bartol, 1980). In these studies, leadership was typically assessed toward the end of the semester by group members' responses to questionnaire measures of leadership contribution.

That women would emerge less commonly than men would be consistent with the research that we have already presented showing that women have to meet a higher standard than men do in order to be considered highly competent and able to lead and that they often elicit disapproval for behaving assertively. In a metaanalysis of 58 studies examining the emergence of leaders, Eagly and Karau (1991) found a small- to moderate-sized tendency for men to emerge more than women (mean $d=0.32$ ) that was somewhat larger when leadership was defined in strictly taskoriented terms (mean $d=0.41$ ). Yet, these results do not necessarily show that women were disadvantaged relative to behaviorally equivalent men, because the emergence sex differences were similar on measures based on perceptions of leadership and measures based on actual behavior (e.g., number of task-oriented contributions; see Bales, 1950).

Consistent with the interactions predicted by our role congruity theory of prejudice, Eagly and Karau's (1991) synthesis also established that several attributes of these studies moderated the relation between gender and the emergence of leaders. Several of these findings are interpretable in terms of the idea that contextual cues affect the particular leadership role that is activated. One such finding is that men emerged strongly when groups were assigned distinctively masculine tasks (e.g., repairing a machine) and less strongly when they were assigned distinctively feminine tasks (e.g., sewing buttons onto a panel). Another such finding is that men's greater emergence weakened for tasks requiring relatively complex social interaction. Leader roles in groups that deal with interpersonally demanding tasks should incorporate social skills and thus present less incongruity with the female gender role. In general, women's positive social contributions become more relevant to leadership for tasks requiring negotiation and extensive sharing of ideas (W. Wood, 1987; W. Wood, Polek, \& Aiken, 1985), allowing women more opportunity to achieve leadership. Similarly, in a subsequent experiment men's substantial leadership advantage in a highly structured game situation eroded in a more interpersonally demanding brainstorming situation (R. J. Hall, Workman, \& Marchioro, 1998). Also relevant to women's contributions to interpersonal relations in groups is the tendency that Eagly and Karau observed for women to emerge more than men on measures of social leadership (mean $d=0.18$ ), which consists of contributing to the maintenance of satisfactory morale and interpersonal relations among group members.

Another predictor of leader emergence in Eagly and Karau's (1991) meta-analysis was the amount of social interaction that had transpired before leadership was assessed: The longer the interaction, the weaker was the tendency for men to emerge. This trend could reflect the lesser influence of gender roles as group members obtain more individuating information about one another. Another possibility is that, because interpersonal cohesion and social concerns become more important in groups that must maintain themselves over time, leaders' roles in such groups incorporate more interpersonal skill and are less incongruent with the female gender role.

In addition, the tendency for men to emerge declined over the years spanned by this research literature. Although this finding is interpretable in terms of a decrease in prejudice, the effect of year of publication became nonsignificant when controls were introduced for other study characteristics (e.g., group size, participant age, social complexity of task). Our examination of studies published subsequent to the meta-analysis suggests that men's leadership advantage still predominates (Dobbins, Long, Dedrick, \& Clemons, 1990; R. J. Hall et al., 1998; Hegstrom \& Griffith, 1992; Malloy \& Janowski, 1992; Sapp, Harrod, \& Zhao, 1996; Walker et al., 1996), although three studies showed no sex difference (Kolb, 1997, 1999; Moss \& Kent, 1996) and one produced a difference in favor of women (Kent \& Moss, 1994).

In summary, because people more easily perceive men as meeting high standards for competence and more readily accept them when they behave confidently and assertively, they are more likely to be thought about as leaders, to behave as leaders, and to emerge as leaders, especially for leader roles given relatively masculine definitions (see also Ridgeway, 2001). Such effects are likely to be important in organizational settings, where people who are perceived as able to lead are more likely to be promoted to higher managerial roles.

\section{Consistency of Research on Access to Leadership Roles With Role Congruity Theory of Prejudice}

In conclusion, a consistent pattern of findings supportive of our theory emerges from very diverse research paradigms. Most studies of actual wages and promotion thus supported the claim of discrimination against women in general and female managers in particular, albeit on a decreasing basis over the years. Goldbergparadigm experiments that obtained evaluations of equivalent female and male job applicants supported the narrower claim of prejudice as disadvantage for women, compared with equivalent men, in relation to male sex-typed positions, which would include most leadership roles. Other studies showed that women usually have to meet a higher standard to be judged as very competent and 
possessing leadership ability and that agentic behavior tends not to produce as much liking or influence for women as men, without special circumstances (e.g., adding communal behavior to an agentic repertoire). Research in addition has demonstrated that it is generally less likely that women, compared with men, emerge as leaders in groups, especially if the group's task is not particularly demanding of interpersonal skill or is otherwise relatively masculine. These findings as well as other findings involving moderating conditions are consistent with the predictions of our role congruity theory of prejudice. Particularly supportive of the overall principle that prejudice lessens women's access to leadership roles is the general consistency of the findings across paradigms that did versus did not equate male and female behavior. The strength of the research support for role congruity theory thus derives from the convergent evidence provided by true experiments, quasi-experiments, organizational studies, and studies using aggregate social statistics such as wages. These paradigms range from those that have excellent internal validity but less external validity to those that have excellent external validity but less internal validity.

\section{Do Female Leaders Face Greater Obstacles to Success in Leadership Roles?}

Because women do occupy leadership roles, it is important to determine whether men and women are perceived and evaluated differently once they attain these roles. According to the role congruity theory of prejudice, in leadership roles with relatively masculine definitions women who are leaders would be targets of two forms of prejudice-a deficit in the ascription of leadership ability to them and, to the extent that they conform to the requirements of a leader role, a less favorable evaluation of their agentic leadership behavior compared with that of men. Relevant to these claims are studies of the effectiveness of men and women who occupy leadership roles in organizations and laboratory groups. Yet, these effectiveness studies present considerable ambiguity not only because male and female behavior was free to vary but also because they typically did not establish the equivalence of male and female leaders on characteristics other than their sex. Therefore, it is especially important to examine in addition a group of Goldberg-paradigm experiments on leadership behavior that established this equivalence.

\section{Studies of Leader Effectiveness}

According to role congruity theory, prejudice may serve to reduce the effectiveness of women who attain leadership roles. Although from a strictly structural perspective, leadership roles in organizations might yield expectations that are powerful enough to overwhelm the influence of gender roles (e.g., Kanter, 1977), our theory maintains that expectations about leaders generally reflect an integration of the descriptive content of the leader role and the gender role. Because the communal characteristics ascribed to women are different from the predominantly agentic characteristics ascribed to leaders, this combining would produce disadvantage for women, especially in leadership roles given more masculine definitions. Yet, to the extent that strong and consistent evidence might cause perceivers to recognize that a woman adheres to the agentic requirements of a leader role, she would likely fall short of the injunctive requirements of the female role. Not only could women in leadership roles be subject to these two forms of prejudicial disadvantage and the negative attitudes that result from them but also they could manifest diminished self-confidence (Lenny, 1977) and expectancy-confirming behavior (Geis, 1993) because of people's negative preconceptions. However, even obtaining no sex difference in effectiveness, averaged across a group of studies, would not mean that sex is inconsequential. Rather, the effect of sex should vary substantially across social settings, in accordance with the moderating variables of our role congruity theory of prejudice.

To address these issues, Eagly, Karau, and Makhijani (1995) conducted a meta-analysis of 96 studies that compared the effectiveness of male and female leaders. Most of these studies were conducted in organizational settings, although a minority examined laboratory groups. The male and female leaders held the same role, albeit a role that was sometimes broadly defined (e.g., middle managers in one or more industries) and sometimes narrowly defined (e.g., middle-school principals in a particular city). Most of these studies assessed effectiveness using subjective ratings of performance or effectiveness, and a minority included more objective measures of performance. This literature thus encompassed studies of performance appraisals of male and female managers (see Bartol, 1999).

The quite heterogeneous findings of these studies were successfully predicted by moderating variables that produced tests of the role congruity theory proposition that women are relatively less effective to the extent that leadership roles are defined in predominantly masculine terms. First, women were less effective than men to the extent that leadership positions were male dominated. Second, female leaders became less effective relative to male leaders as the proportion of male subordinates increased, perhaps reflecting male (vs. female) subordinates' construal of leadership in more masculine terms and greater approval of traditional gender roles. Third, the greater the proportion of men among the raters whose data produced the measures of effectiveness (these raters were not necessarily leaders' subordinates), the less was the effectiveness of women relative to men (see Bowen, Swim, \& Jacobs, 2000, for a similar effect). Fourth, women were substantially less effective than men in military organizations, a traditionally masculine environment, but modestly more effective than men in organizations in the domains of education, government, and social service. Fifth, women fared particularly well in effectiveness, relative to men, in middle-level leadership positions, as opposed to line or supervisory positions. This finding is consistent with the definition of middle management as requiring the type of interpersonal skills that are in the communal repertoire (e.g., Paolillo, 1981).

Eagly et al.'s (1995) most detailed empirical test of the principle that the masculinity of leader roles affects whether men or women are more effective entailed having a group of respondents rate each of the leadership roles in the meta-analytic sample of effectiveness studies and correlating these ratings with the studies' effect sizes, which represented the comparison between male and female leaders' effectiveness. The respondents thus rated how competent they thought they would be in each role and how interested they would be in performing each role. A leadership role was considered congruent with the male gender role if the male respondents indicated more competence and interest and congruent with the female gender role if the female respondents indicated more com- 
petence and interest. The respondents also rated how interested the average man and the average woman would be in occupying each leadership role; roles were considered more masculine if the respondents thought men were more interested and more feminine if they thought that women were more interested. A role was also considered masculine to the extent that the respondents rated it as requiring the ability to direct and control people and feminine to the extent that they rated it as requiring the ability to cooperate and get along with other people.

Using these multiple measures to represent leader roles' congruity with the male and female gender role, Eagly et al. (1995) found that the relative effectiveness of female leaders compared with their male counterparts decreased substantially for the roles rated as more congruent with the male gender role and increased for the roles rated as more congruent with the female gender role. These ratings also confirmed that (a) military roles, which strongly favored men's effectiveness, were especially congruent with the male gender role, and (b) middle management roles, which favored women's effectiveness, were congruent with the female gender role, particularly in terms of being perceived to require interpersonal ability.

In view of these consistent role congruity effects, the overall sex difference in effectiveness in the Eagly et al. (1995) meta-analysis is a somewhat arbitrary statistic, because its magnitude and direction would depend on the balance of more masculine or more feminine leadership roles that happened to be represented in the sample of studies. Moreover, although an array of prejudicial forces may decrease women leaders' chances of obtaining favorable evaluations in many leadership roles, there exists a potentially important factor that could have the opposite impact. Namely, to the extent that qualified women faced discrimination in attaining leadership positions or hesitated to become candidates because of expected discrimination or other considerations, those women who actually obtained these positions might on average be more competent than their male counterparts and thus could have a performance advantage due to the higher standard that they have met.

Overall, there was no difference in the relative effectiveness of male and female leaders (mean $d=-0.02$, indicating nonsignificantly greater female effectiveness). This finding is not surprising, given the competing predictions that we have highlighted as well as the fact that only one study in the sample examined leadership at a level higher than middle management. Nevertheless, this finding is important in applied terms because it suggests that women who actually serve as leaders and managers are in general performing as well as their male counterparts.

In summary, studies of leaders' effectiveness showed consistent role congruity effects, such that leaders performed more effectively when the leader role that they occupied was congruent with their gender role. Women suffered diminished outcomes in roles given especially masculine definitions, and men suffered somewhat poor outcomes in roles given more feminine definitions. These findings provide very strong support not only for the overall predictions of our theory of prejudice but also for its moderating conditions. However, it is important to examine findings in yet another research paradigm, one that removes possible differences in the leadership behavior of women and men by equating this behavior. ${ }^{4}$ These studies can make a stronger case that it is prejudice and not other factors that produce disadvantage for women in leadership roles given relatively masculine definitions.

\section{Goldberg-Paradigm Experiments on Evaluations of Leaders}

To maximize internal validity in investigating prejudice toward women in leadership roles, many researchers have used the Goldberg paradigm to examine evaluations of the leadership behavior of women and men. As in the résumé experiments that we discussed above, the characteristics of stimulus persons other than their sex were held constant, and their sex was varied. Although the majority of these experiments presented written vignettes describing leaders' behavior (e.g., Rosen \& Jerdee, 1973), some of the experiments presented male and female confederates who had been trained to lead research participants in particular styles (e.g., D. M. Lee \& Alvares, 1977). The samples of evaluators in these experiments consisted primarily of undergraduate students but included high school students and graduate students as well as managers and other employees.

Eagly, Makhijani, and Klonsky (1992) provided a meta-analysis of 61 of these Goldberg-paradigm experiments in which the stimuli presented to participants were leadership behaviors ascribed to women or men. As predicted by the role congruity theory of prejudice, the meta-analysis showed that the devaluation of female leaders was greater, relative to their male counterparts, for maledominated leadership roles. This regularity is theoretically sensible because expectations for male-dominated leadership roles should be more extremely agentic. Consistent with this finding and with our broader argument that the organizational context influences the definition of leadership roles, prejudice against female leaders was very strong in the subgroup of these Goldberg experiments that portrayed men and women as basketball coaches. As also predicted by our theory, the devaluation of female leaders was greater when men served as evaluators. ${ }^{5}$

One of the most important findings of this meta-analysis is that women in leadership positions were devalued more strongly, relative to their male counterparts, when leadership was carried out in stereotypically masculine styles, particularly when this style was autocratic or directive (mean $d=0.30$ for autocratic styles). This moderating condition thus fit our role congruity prediction that prejudice is more likely when female leaders violate their gender role by fulfilling leadership roles in an especially agentic style. Subsequent research has continued to confirm that autocratic or dominating leadership behavior is less well received from female than male leaders (Copeland, Driskell, \& Salas, 1995; Korabik, Baril, \& Watson, 1993; but see Luthar, 1996).

Individual experiments presenting standardized managerial be-

\footnotetext{
${ }^{4}$ Eagly et al. (1995) examined the equivalence of the male and female leaders who were compared in the effectiveness studies by coding whether the male-female comparison was known to have been confounded with variables such as seniority, education, and age or was likely or unlikely to have been confounded. This variable did not moderate the sex differences in effectiveness.

${ }^{5}$ Eagly et al.'s (1992) meta-analysis also showed a tendency for the devaluation of female leaders to increase over time, contrary to the prediction of our theory. However, this relation became null in a multiple regression that controlled for other study characteristics, suggesting that its significance in a univariate analysis was due to its confounding with other study characteristics.
} 
havior have produced some of the interactions that our theory predicts should follow from increasing the accessibility of the female gender role. Specifically, portraying a woman as pregnant lowered evaluations of her performance in assessment-center tasks (Halpert, Wilson, \& Hickman, 1993) or in role-playing of responses to workplace conflict (Corse, 1990). Also, physical attractiveness detrimentally affected the perceived capability of a female executive and lessened the ascription of her success to ability, whereas attractiveness enhanced these perceptions for a male executive (Heilman \& Stopeck, 1985a). In addition, performance reviews of attractive men and women showed that attractiveness was disadvantageous for women in managerial positions but advantageous for women in nonmanagerial positions and had no impact on perceptions of men (Heilman \& Stopeck, 1985b). ${ }^{6}$

The overall tendency to be more prejudiced toward one sex than the other is somewhat arbitrary in this meta-analysis, just as it was in the Eagly et al. (1995) meta-analysis of effectiveness, because its magnitude and direction would depend on the balance of more masculine or more feminine leadership roles and behaviors represented in the sample of studies. Moreover, expectations for the overall prejudicial effect must take into account that very few of the studies in this literature portrayed leadership at a level beyond middle management, and the majority portrayed supervision (i.e., line management). Therefore, given our assumption that prejudice against female leaders is especially likely beyond the middlemanagement level, it is not surprising that the meta-analysis showed only a small (yet significant) overall tendency for participants to evaluate female leaders less favorably than male leaders (mean $d=0.05$ ).

The small size of the overall effect in this meta-analysis as well as the one on leader effectiveness raises the question of whether under some conditions women are more successful than men as leaders. This possibility is consistent with our role incongruity theory to the extent that some leader roles have a definition that is more feminine than masculine. The Eagly et al. (1995) metaanalysis on leader effectiveness confirmed this possibility by finding women more effective than men as leaders in educational organizations as well as government and social service organizations. Although the advantage of women over men in these settings was small, studies in these settings were fairly frequent in the meta-analysis, thus balancing the studies in which men fared better than women, especially studies conducted in military organizations. Also, Davison and Burke's (2000) meta-analysis of experiments involving job résumés or applications obtained clear evidence of female advantage for female-typed jobs, although presumably few of these jobs were leadership roles. However, advantage for female leaders was absent in the Eagly et al. (1992) meta-analysis of Goldberg-paradigm experiments, in which even the more feminine leadership styles and the less male-dominated roles did not yield significant tendencies for women to be evaluated more positively than men.

A reservation about generalizing the findings of Goldbergparadigm experiments on leadership behavior to natural settings is that organizational evaluators often have much more information available to them than presented in the vignettes or scenarios used in these experiments. Although the extensiveness of the information researchers presented did not relate to the amount of bias in Eagly et al.'s (1992) meta-analysis, a considerably greater amount of information might dampen the effect of target persons' sex (e.g., Swim et al., 1989; Tosi \& Einbender, 1985).

Despite these reservations, there is impressive consistency of findings across the leader effectiveness paradigm, which examined evaluations of actual leaders, and the leader evaluation (i.e., Goldberg) paradigm, which examined evaluations of leaders whose behavior had been experimentally equated. In both types of studies, women fared less well than men when leader roles were male dominated or given especially masculine definitions and when men served as evaluators. This parallelism makes it plausible that the effectiveness findings are not due merely to differing behavior on the part of male and female leaders but are due at least in part to differential reactions to equivalent male and female behavior. Moreover, these meta-analytic findings are consistent with research on attributions for success and failure, which can be interpreted as a less direct measure of prejudice. Swim and Sanna's (1996) meta-analysis thus showed that, on masculine tasks, people attribute men's successes, more than women's successes, to the stable cause of ability and women's successes to the unstable cause of effort. For failures on masculine tasks, the logic reversed: People attribute women's failures, more than men's failures, to the stable cause of lack of ability and men's failures to the unstable causes of low effort and bad luck.

Also lending plausibility to our interpretation is the match between these findings and the particulars of certain sex discrimination cases that have been brought to trial. Burgess and Borgida (1999) provided an insightful analysis of the relation of gender stereotyping to such cases, the most famous of which is Price Waterhouse v. Hopkins $(1987,1989)$. This case pertained to Ann Hopkins, a woman who approached her work at a large accounting firm with a forthright, agentic style (S. T. Fiske, Bersoff, Borgida, Deaux, \& Heilman, 1991). Although her task competence was acknowledged, she was denied partnership essentially on the basis of her lack of conformity to the female gender role. According to the role congruity theory of prejudice toward female leaders, this reaction could be viewed as part of a larger pattern of prejudice that places women in male-dominated roles at risk for discrimination, particularly if they have an agentic style.

\section{Conclusion}

We proposed a theory of prejudice against female leaders that is based on an analysis of the descriptive and injunctive aspects of gender roles. This analysis led us to argue that prejudice toward female leaders consists of two types of disadvantage: (a) Deriving from the descriptive aspect of the female gender role is the perception of women as possessing less leadership ability than men, and (b) deriving from the injunctive aspect of the female gender role is the less favorable evaluation of behavior that fulfills the prescriptions of a leader role (and thereby violates the female gender role) when this behavior is enacted by a woman compared with a man. Our theory states that the first type of disadvantage

\footnotetext{
${ }^{6}$ Another interaction predicted by our theory was demonstrated in experiments that did not involve leadership behavior but behavior in a male-dominated occupation (police officer). Specifically, bias against women was greater when cognitive resources were depleted by competing attentional demands or time pressures (Martell, 1991) or when ratings were delayed by 5 days (Martell, 1996).
} 
stems from social perceivers' combining of the descriptive aspects of the gender and leader roles. This blending produces the perception that women, compared with equivalent men, possess less agency and more communion and therefore are less qualified for leadership, especially for executive roles. In addition, to the extent that women completely fulfill a leader role, the weight given to the descriptive aspects of the female gender role should lessen, but the injunctive aspects of this role would produce prejudice because such behavior by a woman would be inconsistent with many people's beliefs about desirable female behavior. These two forms of disadvantage would produce the consequences that are demonstrated by the findings that we have presented in this article: (a) less favorable attitudes toward female than male leaders, (b) greater difficulty for women in attaining leadership roles, and (c) greater difficulty for women in being recognized as effective in these roles.

Our role congruity theory proposed that prejudice toward female leaders would be a variable phenomenon that would depend on several determinants. The first form of prejudice would in particular depend on the definition of particular leader roles and the weight given to the female gender role relative to the leader role. Therefore, consistent with this theory and especially relevant to the glass ceiling metaphor, women fared less well in relation to roles given particularly masculine definitions, including executive roles. Moreover, reflecting sex differences in attitudes toward traditional gender roles and in definitions of leadership roles, men often showed stronger prejudice than women when data were separated by sex of participant. Similarly, female disadvantage often lessened over the years when data were collected, perhaps due to change of attitudes about gender roles over time and change in the definition of leader roles. Also, conditions postulated to increase the weight given to the female gender role (e.g., physical attractiveness, pregnancy, statistical rarity) were associated with greater female disadvantage. In addition, reflecting the injunctive aspects of the female role, women's especially agentic behavior tended to produce negative reactions, whether delivered in a leaderless situation or as a leader, especially from male observers.

The basic principles that we have articulated in our role congruity theory of prejudice lend themselves to a wide range of new tests, because many variables, in addition to those already studied, could affect the degree of incongruity between leadership roles and the female (and male) gender roles as well as the weight given to gender roles. For example, little attention has so far been directed to subcultural and cultural variation in definitions of gender roles and leader roles, whereby in some societal and organizational contexts the female gender role and leader roles may not be as inconsistent as they are in other contexts. With explicit consideration of the principles of the role congruity theory and the relevance of contextual and individual-differences variables to these principles, researchers and organizational consultants would be able to anticipate whether gender prejudice is likely in relation to selecting people for leadership roles and evaluating people who occupy these roles. The identification of likely contexts for prejudice could foster interventions that prevent discrimination.

Critics of the evidence we have provided might take the position that, given the small size of the prejudicial effects demonstrated in many of the meta-analyses and individual studies that we have cited, often accounting for between $1 \%$ and $5 \%$ of the variability, prejudice cannot explain the lack of women in high-level leader- ship positions (e.g., Arvey \& Murphy, 1998; Latham, 1986). In concert with Martell (1999), we disagree with any such judgment and point out that small biases, when repeated over individuals and occasions, can produce large consequences. Using computer simulation, Martell, Lane, and Emrich (1996) demonstrated that a small bias against women of $1 \%$ of the variance in initial performance ratings produced senior management levels with only $35 \%$ women, and a 5\% initial bias produced only $29 \%$ senior women. Martell (1999) subsequently showed that introducing a very small bias against women at each yearly review readily creates the tiny proportions of female senior executives that are typical of corporations. Slight prejudice that is consistently acted on greatly reduces women's chances of rising to high-level positions in organizations.

Finally, we remind readers that our theory and associated review of evidence have the specific goal of determining the extent to which prejudice is one factor accounting for the relative lack of women in positions that yield high levels of power and authority. We believe that the skepticism that some critics of the prejudice argument have expressed (e.g., Browne, 1999) stems in large part from social scientists' failure to provide a sophisticated treatment of what prejudice is and to rigorously review evidence relevant to such a treatment. Although we have corrected these omissions, we have not evaluated other theories of women's underrepresentation as leaders or compared the importance of prejudice relative to other factors that may prevent women from entering leadership roles. Our presentation of a theory of prejudice along with related research should foster such comparative efforts in the future.

\section{Effects on Behavior}

Consistent with our general assumption that prejudiced beliefs produce or maintain subordination of social groups, one important route by which prejudice produces subordination is influence on the behavior of group members. Women and men who are leaders or potential leaders may thus differ systematically in their beliefs, attitudes, and behaviors. Although the literature relevant to evaluating such a proposition is far too large and complex to review in this article, we note the kinds of effects on behavior that are well illuminated by our analysis.

As predicted by Eagly's (1987; Eagly et al., 2000) social role theory of sex differences and similarities, expectancies associated with gender roles foster behaviors consistent with these roles through expectancy confirmation processes. Stereotypical expectancies are especially powerful (Snyder, 1981), and genderstereotypical expectancies have yielded some of the clearest demonstrations of behavioral confirmation (e.g., Skrypnek \& Snyder, 1982; see the review by Geis, 1993). This power of gender roles to influence behavior has also been shown in studies of stereotype threat (Steele, 1997), which include demonstrations of the undermining of women's math performance by anxiety about confirming people's expectations about women's inferior ability (Spencer, Steele, \& Quinn, 1999).

Also relevant to the effects of gender roles on behavior are self-regulatory processes (see Eagly et al., 2000). As Ely (1994, 1995) has shown, women's social identities in their workplaces reflect prevailing gender stereotypes, especially in organizations with low proportions of women in senior positions. Women may thus behave gender stereotypically because of having internalized 
aspects of gender roles, especially if situational cues make these aspects particularly accessible. In general, through self-regulatory and expectancy confirmation processes, gender roles can induce sex differences in behavior in the absence of any intrinsic, inborn psychological differences between women and men. Moreover, to the extent that women have internalized the traditional female gender role, they may be less attracted to leadership roles (Lips, 2000), especially top management positions, and therefore be less likely to strive for promotion into such positions (Van Vianen \& Fischer, 2000).

The role congruity theory of prejudice maintains that gender roles influence behavior even in the presence of a competing leadership role. It is thus plausible that the behavioral sex differences manifested by people who occupy leadership roles are mediated at least in part by the prejudiced reactions that we have identified. Various studies thus suggest that female managers have a behavioral repertoire that includes more communal features than that of male managers. For example, in a study of middle managers' self-reports of how they influence their organizational superiors, female managers, more than male managers, reported that they acted more out of organizational interest than self-interest, considered others' viewpoints, and focused on the interpersonal aspects as well as the task aspects of the influence episode (Lauterbach \& Weiner, 1996). Also, in a study using an experiencesampling method in work settings, both men and women reported behaving more agentically in relation to their subordinates than their bosses, but women reported a more agreeable, communal style, regardless of their own organizational status in relation to their interaction partners (Moskowitz, Suh, \& Desaulniers, 1994). Similarly, a study of employees carrying out structured tasks in dyadic interactions found that, regardless of employees' organizational status, the women, compared with the men, manifested a warmer, more expressive nonverbal style, as conveyed by their face, body, and voice quality, as well as less vocal dominance (J. A. Hall \& Friedman, 1999). More generally, Eagly and Johnson's (1990) meta-analysis of 162 studies comparing the leadership styles of women and men found a tendency for women to lead in a more democratic and participative style than men. In addition, other meta-analytic evidence showed that women, more than men, adopt a transformational style (Bass, 1998), especially the aspect of this style that involves focusing on the development and mentoring of followers and attending to followers' individual needs (Eagly \& Johannesen-Schmidt, 2001; Eagly, Johannesen-Schmidt, van Engen, \& Vinkenburg, 2002). Our role congruity theory and the evidence we have reviewed earlier in this article suggest that such stylistic sex differences may stem from the influence of the injunctive aspects of the female gender role. Women thus receive more disapproving and uncooperative reactions than men do when they proceed in an assertive and directive manner. However, these unfavorable reactions may dissipate at least partially when women complement their agentic repertoire with communal behaviors that are consistent with the female gender role, as long as these behaviors do not violate the relevant leadership role.

Consistent with the idea that gender roles affect female leaders' behavior is the commonly expressed opinion that their behavior is constrained to a somewhat less agentic, more communal repertoire than that of male leaders, in women's efforts to avoid the Scylla of the descriptive implications of the female gender role and the Charybdis of its injunctive aspects. Many writers have thus com- mented on the fine line that female leaders must walk to avoid negative evaluations. For example, Morrison, White, and Van Velsor (1987) noted the "narrow band of acceptable behavior" (p. 87) allowed for women leaders-behaviors that are somewhat feminine but not too feminine and somewhat masculine but not too masculine. Sheppard (1992) argued that managerial women strive to display behavior that is both sufficiently businesslike and professional that they are credible as managers and sufficiently feminine that they do not challenge prevailing assumptions about gender. Although women's careful balancing of the masculine and feminine aspects of their behavior may produce effective influence and personal acceptance in many situations, it may compromise their advancement to higher level positions because their behavior may appear less powerful and confident than that of their male counterparts. Thus, the lack of ascendance of women to executive roles, which are perceived to require a highly agentic set of behaviors (Martell et al., 1998), may result at least in part from this accommodation of women to the two forms of prejudice delineated by our theory. Other causes also merit attention, especially the organizational practices through which prejudice is transformed into discriminatory actions (see Collinson, Knights, \& Collinson, 1990; Martin, 1992; Ragins \& Sundstrom, 1989).

\section{Possibilities for Change}

A lessening of the prejudice that is directed toward female leaders and potential leaders would require change in gender roles or leader roles or both. Possibilities for change in gender roles must take into account that these roles are emergents from the activities carried out by individuals of each sex in their sex-typical occupational and family roles. Therefore, change in the descriptive norms underlying gender roles would require general societal change in the distribution of men and women into social roles. Despite such change - that is, the widespread entry of women into the paid labor force - the descriptive content of gender roles appears to have remained fairly constant across the limited span of years for which data exist (e.g., Lueptow et al., 1995; Spence \& Buckner, 2000). This relative constancy can appear puzzling in the face of decreasing acceptance of the injunctive content of gender roles (e.g., Twenge, 1997).

The relative constancy of perceivers' descriptive beliefs about men and women may reflect the tendency for occupations to remain relatively segregated by sex along gender-stereotypical lines (Cejka \& Eagly, 1999) and for domestic labor to remain mainly a female responsibility (Bianchi, Milkie, Sayer, \& Robinson, 2000). Nonetheless, the decreasing approval of traditional gender differentiation may reflect the considerable change in the status of women that has occurred as women shifted from domestic labor to wage labor. In view of this transformation of women's roles in the 20th century, it is not surprising that social perceivers also understand that women are a social group undergoing change-in other words, women have a dynamic stereotype characterized by an increase in agentic personality characteristics (Diekman \& Eagly, 2000). The belief that women are adopting and will continue to adopt the agentic characteristics that have traditionally been associated with leaders may increase women's opportunities to assume leadership roles. 
Prejudice toward female leaders may also be lessened by change in the content of leader roles. If these roles were to evolve in a direction requiring more of the communal characteristics typically ascribed to women and fewer of the agentic characteristics typically ascribed to men, the existing female gender role would become more congruent with leader roles, and female leaders should experience decreased prejudice and increased acknowledgment of their effectiveness. ${ }^{7}$

Some leader roles may already be changing toward more androgynous definitions as shown by women's construals of managerial roles (Schein, 2001). Moreover, rapidly changing, globally competitive, high-technology environments may be inducing many organizations to adopt flatter, less centralized, more flexible structures and to develop participatory, delegatory, opencommunication strategies conducive to rapid adaptation and responsiveness to customers (e.g., Drucker, 1988; Hitt, Keats, \& DeMarie, 1998; Volberda, 1998). Thus, the traditional view of management may emphasize autocratic and directive control mechanisms that are too rigidly bureaucratic and hierarchical to be effective in many modern organizations (e.g., Kanter, 1997; Kanter, Stein, \& Jick, 1992; Offermann \& Gowing, 1990; T. Peters, 1988).

Organizational scholars have offered a host of new perspectives on leadership that construe management in terms that are more congenial to the female gender role than traditional views. These perspectives emphasize democratic relationships, participatory decision making, delegation, and team-based leadership skills that are consistent with the democratic leadership styles actually adopted by many female managers (Eagly \& Johnson, 1990) as well as the communal characteristics typically ascribed to women. For example, proponents of learning organizations (e.g., Garvin, 1993; Senge, 1990) emphasize effective communication, supportiveness, participation, and team-based learning as central elements of organizational effectiveness. Similarly, continuous quality improvement theorists and practitioners (e.g., Deming, 1986; Juran, 1988) emphasize the importance of building cooperation rather than competition, developing teamwork skills, building long-term relationships with suppliers, empowering all employees to make decisions that can improve the quality of their work, and removing sources of fear and intimidation from the workplace (see the review by Hackman \& Wageman, 1995). Confirming that current expert opinion on desirable modes of management features behaviors considered to be feminine is Fondas's (1997) textual analysis of mass-market books exemplifying contemporary advice on management. In addition, several researchers have explicitly advocated a shift to a more feminine style of leadership. For example, Loden (1985) advanced a feminine leadership model characterized by cooperation and collaboration between managers and subordinates. Helgesen (1990) argued for a feminine principle in leadership characterized by an emphasis on cooperation rather than competition and equality rather than a superior-subordinate hierarchy. Similarly, Rosener (1995) extolled female managers' interactive form of leadership, whose characteristics include encouraging participation, sharing information and power, and enhancing others' self-worth. To the extent that organizations shift away from a traditional view of leadership and toward the more democratic and participatory view advocated by many modern management scholars, women should experience reduced prejudice and gain in- creased representation and acceptance in leadership roles in the future.

\footnotetext{
${ }^{7}$ Some caution concerning this prediction follows from Rudman and Glick's (1999) experiment, which showed that a managerial role described as requiring communal qualities disadvantaged agentic female job applicants relative to their agentic male counterparts. These women were viewed as less socially skilled than equivalent men, presumably because their agentic qualities violated descriptive and prescriptive requirements of the female gender role. However, the description of agentic qualities in this experiment involved extremely competitive and dominating behavior.
}

\section{References}

Abramson, P. R., Goldberg, P. A., Greenberg, J. H., \& Abramson, L. M. (1977). The talking platypus phenomenon: Competency ratings as a function of sex and professional status. Psychology of Women Quarterly, 2, 114-124.

Adler, N. J., \& Izraeli, D. N. (1994). Competitive frontiers: Women managers in a global economy. Cambridge, MA: Blackwell.

Aguinis, H., \& Adams, S. K. R. (1998). Social-role versus structural models of gender and influence use in organizations: A strong inference approach. Group \& Organization Management, 23, 414-446.

Alexander, L. D. (1979). The effect level in the hierarchy and functional area have on the extent Mintzberg's roles are required by managerial jobs. Academy of Management Proceedings, 39, 186-189.

Allport, G. W. (1954). The nature of prejudice. Reading, MA: AddisonWesley.

Altemeyer, R. A., \& Jones, K. (1974). Sexual identity, physical attractiveness and seating position as determinants of influence in discussion groups. Canadian Journal of Behavioural Science, 6, 357-375.

Arkkelin, D., \& Simmons, R. (1985). The "good manager": Sex-typed, androgynous, or likable? Sex Roles, 12, 1187-1198.

Arvey, R. D. (1979). Unfair discrimination in the employment interview: Legal and psychological aspects. Psychological Bulletin, 86, 736-765.

Arvey, R. D., \& Murphy, K. R. (1998). Performance evaluation in work settings. Annual Review of Psychology, 49, 141-168.

Ashmore, R. D., Solomon, M. R., \& Longo, L. C. (1996). Thinking about fashion models' looks: A multidimensional approach to the structure of perceived physical attractiveness. Personality and Social Psychology Bulletin, 22, 1083-1104.

Atwater, L. E., Carey, J. A., \& Waldman, D. A. (in press). Gender and discipline in the workplace: Wait until your father gets home. Journal of Management.

Bakan, D. (1966). The duality of human existence: An essay on psychology and religion. Chicago: Rand McNally.

Bales, R. F. (1950). Interaction process analysis: A method for the study of small groups. Cambridge, MA: Addison-Wesley.

Banaji, M. R., \& Hardin, C. D. (1996). Automatic stereotyping. Psychological Science, 7, 136-141.

Banaji, M. R., Hardin, C. D., \& Rothman, A. J. (1993). Implicit stereotyping in person judgment. Journal of Personality and Social Psychology, 65, 272-281.

Bartol, K. M. (1999). Gender influences on performance evaluations. In G. N. Powell (Ed.), Handbook of gender \& work (pp. 165-178). Thousand Oaks, CA: Sage.

Bass, B. M. (1990). Bass \& Stogdill's handbook of leadership: Theory, research, and managerial applications (3rd ed.). New York: Free Press.

Bass, B. M. (1998). Transformational leadership: Industrial, military, and educational impact. Mahwah, NJ: Erlbaum.

Bayard, K., Hellerstein, J., Neumark, D., \& Troske, K. (1999). New evidence on sex segregation and sex differences in wages from matched 
employee-employer data (Working Paper No. 7003). Cambridge, MA: National Bureau of Economic Research.

Berger, J., Norman, R. Z., Balkwell, J. W., \& Smith, R. F. (1992). Status inconsistency in task situations: A test of four status processing principles. American Sociological Review, 57, 843-855.

Berger, J., Webster, M., Jr., Ridgeway, C. L., \& Rosenholtz, S. J. (1986). Status cues, expectations, and behavior. In E. Lawler (Ed.), Advances in group processes (Vol. 3, pp. 1-22). Greenwich, CT: JAI Press.

Bergmann, B. R. (1989). Does the market for women's labor need fixing? Journal of Economic Perspectives, 3, 43-60.

Best, D. L., \& Williams, J. E. (1993). A cross-cultural viewpoint. In A. E. Beall \& R. J. Sternberg (Eds.), The psychology of gender (pp. 215-248). New York: Guilford Press.

Bianchi, S. M., Milkie, M. A., Sayer, L. C., \& Robinson, J. P. (2000). Is anyone doing the housework? Trends in the gender division of household labor. Social Forces, 79, 191-228.

Biddle, B. J. (1979). Role theory: Expectations, identities, and behaviors. New York: Academic Press.

Bieber, L., \& Dipboye, R. L. (1988, April). Physical attractiveness biases in evaluations of applicants: Are they generalizable? Poster session presented at the meeting of the Society for Industrial and Organizational Psychology, Dallas, TX.

Biernat, M. (1995). The shifting standards model: Implications of stereotype accuracy for social judgment. In Y. Lee, L. Jussim, \& C. R. McCauley (Eds.), Stereotype accuracy: Toward appreciating group differences (pp. 87-114). Washington, DC: American Psychological Association.

Biernat, M., Crandall, C. S., Young, L. V., Kobrynowicz, D., \& Halpin, S. M. (1998). All that you can be: Stereotyping of self and others in a military context. Journal of Personality and Social Psychology, 75, 301-317.

Biernat, M., \& Kobrynowicz, D. (1997). Gender- and race-based standards of competence: Lower minimum standards but higher ability standards for devalued groups. Journal of Personality and Social Psychology, 72, 544-557.

Blair, I. V., \& Banaji, M. R. (1996). Automatic and controlled processes in stereotype priming. Journal of Personality and Social Psychology, 70, $1142-1163$

Blau, F. D., \& Ferber, M. A. (1987). Occupations and earnings of women workers. In K. S. Koziara, M. J. Moskow, \& L. D. Tanner (Ed.), Working women: Past, present, future (pp. 37-68). Washington, DC: Bureau of National Affairs.

Bowen, C., Swim, J. K., \& Jacobs, R. R. (2000). Evaluating gender biases on actual job performance of real people: A meta-analysis. Journal of Applied Social Psychology, 30, 2194-2215.

Bowman, G. W., Worthy, N. B., \& Greyser, S. A. (1965). Are women executives people? Harvard Business Review, 43(4), 14-28, 164-178.

Broverman, I. K., Vogel, S. R., Broverman, D. M., Clarkson, F. E., \& Rosenkrantz, P. S. (1972). Sex-role stereotypes: A current appraisal. Journal of Social Issues, 28(2), 59-78.

Browne, K. (1999). Divided labours: An evolutionary view of women at work. New Haven, CT: Yale University Press.

Burgess, D., \& Borgida, E. (1999). Who women are, who women should be: Descriptive and prescriptive gender stereotyping in sex discrimination. Psychology, Public Policy, and Law, 5, 665-692.

Butler, D., \& Geis, F. L. (1990). Nonverbal affect responses to male and female leaders: Implications for leadership evaluations. Journal of Personality and Social Psychology, 58, 48-59.

Carli, L. L. (1990). Gender, language, and influence. Journal of Personality and Social Psychology, 59, 941-951.

Carli, L. L. (1998, June). Gender effects in social influence. Paper presented at the meeting of the Society for the Psychological Study of Social Issues, Ann Arbor, MI.

Carli, L. L., \& Eagly, A. H. (1999). Gender effects on influence and emergent leadership. In G. N. Powell (Ed.), Handbook of gender \& work (pp. 203-222). Thousand Oaks, CA: Sage.

Carli, L. L., LaFleur, S. J., \& Loeber, C. C. (1995). Nonverbal behavior, gender, and influence. Journal of Personality and Social Psychology, 68, 1030-1041.

Carpenter, S. J. (2001). Implicit gender attitudes (Doctoral dissertation, Yale University, 2000). Dissertation Abstracts International, 61, 5619. Cash, T. F., Gillen, B., \& Burns, D. S. (1977). Sexism and beautyism in personnel consultant decision making. Journal of Applied Psychology, 62, 301-310.

Catalyst. (2000). Census of women corporate officers and top earners. New York: Catalyst.

Cejka, M. A., \& Eagly, A. H. (1999). Gender-stereotypic images of occupations correspond to the sex segregation of employment. Personality and Social Psychology Bulletin, 25, 413-423.

Center for the American Woman and Politics. (2001). Fact sheet. Retrieved June 6, 2001, from Rutgers University, Eagleton Institute of Politics, Center for the American Woman and Politics Web site: http://www.rci. rutgers.edu/ cawp/pdf/elective.pdf

Cialdini, R. B., \& Trost, M. R. (1998). Social influence: Social norms, conformity, and compliance. In D. T. Gilbert, S. T. Fiske, \& G. Lindzey (Eds.), The handbook of social psychology (4th ed., Vol. 2, pp. 151192). Boston: McGraw-Hill.

Cleveland, J. N. (1991). Using hypothetical and actual applicants in assessing person-organization fit: A methodological note. Journal of Applied Social Psychology, 21, 1004-1011.

Cohen, L. E., Broschak, J. P., \& Haveman, H. A. (1998). And then there were more? The effect of organizational sex composition on the hiring and promotion of managers. American Sociological Review, 63, 711727.

Collinson, D. L., Knights, D., \& Collinson, M. (1990). Managing to discriminate. New York: Routledge.

Copeland, C. L., Driskell, J. E., \& Salas, E. (1995). Gender and reactions to dominance. Journal of Social Behavior and Personality, 10, 53-68.

Corse, S. J. (1990). Pregnant managers and their subordinates: The effects of gender expectations on hierarchical relationships. Journal of Applied Behavioral Science, 26, 25-47.

Cota, A. A., Reid, A., \& Dion, K. L. (1991). Construct validity of a diagnostic ratio measure of gender stereotypes. Sex Roles, 25, 225-235.

Cox, T. H., \& Harquail, C. V. (1991). Career paths and career success in the early career stages of male and female MBAs. Journal of Vocational Behavior, 39, 54-75.

Daubman, K. A., Heatherington, L., \& Ahn, A. (1992). Gender and the self-presentation of academic achievement. Sex Roles, 27, 187-204.

Davison, H. K., \& Burke, M. J. (2000). Sex discrimination in simulated employment contexts: A meta-analytic investigation. Journal of Vocational Behavior, 56, 225-248.

Deaux, K., \& Lewis, L. L. (1983). Components of gender stereotypes. Psychological Documents, 13(2), MS. 258325.

Deaux, K., \& Lewis, L. L. (1984). Structure of gender stereotypes: Interrelationships among components and gender label. Journal of Personality and Social Psychology, 46, 991-1004.

Deming, W. E. (1986). Out of the crisis. Cambridge, MA: Massachusetts Institute of Technology, Center for Advanced Engineering Study.

Devine, P. G., Monteith, M. J., Zuwerink, J. R., \& Elliot, A. J. (1991). Prejudice with and without compunction. Journal of Personality and Social Psychology, 60, 817-830.

Diekman, A. B., \& Eagly, A. H. (2000). Stereotypes as dynamic constructs: Women and men of the past, present, and future. Personality and Social Psychology Bulletin, 26, 1171-1188.

Dipboye, R. L. (1987). Problems and progress of women in management. In K. S. Koziara, M. H. Moskow, \& L. D. Tanner (Eds.), Working women: Past, present, future (pp. 118-153). Washington, DC: Bureau of National Affairs. 
Dipboye, R. L., Arvey, R. D., \& Terpstra, D. E. (1977). Sex and physical attractiveness of raters and applicants as determinants of resume evaluations. Journal of Applied Psychology, 62, 288-294.

Dipboye, R. L., Fromkin, H. L., \& Wiback, K. (1975). Relative importance of applicant sex, attractiveness, and scholastic standing in evaluation of job applicant resumes. Journal of Applied Psychology, 60, 39-43.

Dobbins, G. H., Long, W. S., Dedrick, E. J., \& Clemons, T. C. (1990). The role of self-monitoring and gender on leader emergence: A laboratory and field study. Journal of Management, 16, 609-618.

Dodge, K. A., Gilroy, F. D., \& Fenzel, L. M. (1995). Requisite management characteristics revisited: Two decades later. Journal of Social Behavior and Personality, 10, 253-264.

Dovidio, J. F., Ellyson, S. L., Keating, C. F., Heltman, K., \& Brown, C. E. (1988). The relationship of social power to visual displays of dominance between men and women. Journal of Personality and Social Psychology, 54, 233-242.

Drucker, P. F. (1988). The coming of the new organization. Harvard Business Review, 66(1), 45-53.

Dubno, P. (1985). Attitudes toward women executives: A longitudinal approach. Academy of Management Journal, 28, 235-239.

Dubno, P., Costas, J., Cannon, H., Wanker, C., \& Emin, H. (1979). An empirically keyed scale for measuring managerial attitudes toward women executives. Psychology of Women Quarterly, 3, 357-364.

Dunning, D., \& Sherman, D. A. (1997). Stereotypes and tacit inference. Journal of Personality and Social Psychology, 73, 459-471.

Eagly, A. H. (1987). Sex differences in social behavior: A social-role interpretation. Hillsdale, $\mathrm{NJ}$ : Erlbaum.

Eagly, A. H. (in press). Prejudice: Toward a more inclusive understanding. In A. H. Eagly, R. M. Baron, \& V. L. Hamilton (Eds.), The social psychology of group identity and social conflict: Theory, application, and practice. Washington, DC: APA Books.

Eagly, A. H., \& Chaiken, S. (1993). The psychology of attitudes. Fort Worth, TX: Harcourt Brace Jovanovich.

Eagly, A. H., \& Chaiken, S. (1998). Attitude structure and function. In D. T. Gilbert, S. T. Fiske, \& G. Lindzey (Eds.), The handbook of social psychology (Vol. 1, 4th ed., pp. 269-322). New York: McGraw-Hill.

Eagly, A. H., \& Johannesen-Schmidt, M. C. (2001). The leadership styles of women and men. Journal of Social Issues, 57, 781-797.

Eagly, A. H., Johannesen-Schmidt, M. C., van Engen, M., \& Vinkenburg, C. (2002). Transformational, transactional, and laissez-faire leadership styles: A meta-analysis comparing women and men. Manuscript submitted for publication.

Eagly, A. H., \& Johnson, B. T. (1990). Gender and leadership style: A meta-analysis. Psychological Bulletin, 108, 233-256.

Eagly, A. H., \& Karau, S. J. (1991). Gender and the emergence of leaders: A meta-analysis. Journal of Personality and Social Psychology, 60, 685-710.

Eagly, A. H., Karau, S. J., \& Makhijani, M. G. (1995). Gender and the effectiveness of leaders: A meta-analysis. Psychological Bulletin, 117, 125-145.

Eagly, A. H., Makhijani, M. G., \& Klonsky, B. G. (1992). Gender and the evaluation of leaders: A meta-analysis. Psychological Bulletin, 111, $3-22$.

Eagly, A. H., \& Mladinic, A. (1994). Are people prejudiced against women? Some answers from research on attitudes, gender stereotypes, and judgments of competence. In W. Stroebe \& M. Hewstone (Eds.), European review of social psychology (Vol. 5, pp. 1-35). New York: Wiley.

Eagly, A. H., Wood, W., \& Diekman, A. B. (2000). Social role theory of sex differences and similarities: A current appraisal. In T. Eckes \& H. M. Trautner (Eds.), The developmental social psychology of gender (pp. 123-174). Mahwah, NJ: Erlbaum.

Eckes, T. (1994). Explorations in gender cognition: Content and structure of female and male subtypes. Social Cognition, 12, 37-60.
Ellyson, S. L., Dovidio, J. F., \& Brown, C. E. (1992). The look of power: Gender differences in visual dominance behavior. In C. L. Ridgeway (Ed.), Gender, interaction, and inequality (pp. 50-80). New York: Springer-Verlag.

Ely, R. J. (1994). The effects of organizational demographics and social identity on relationships among professional women. Administrative Science Quarterly, 39, 203-238.

Ely, R. J. (1995). The power in demography: Women's social constructions of gender identity at work. Academy of Management Journal, 38, 589634.

Eskilson, A., \& Wiley, M. G. (1976). Sex composition and leadership in small groups. Sociometry, 39, 183-194.

Esses, V. M., Haddock, G., \& Zanna, M. P. (1993). Values, stereotypes, and emotions as determinants of intergroup attitudes. In D. M. Mackie \& D. L. Hamilton (Eds.), Affect, cognition, and stereotyping: Interactive processes in group perception (pp. 137-166). San Diego, CA: Academic Press.

Fazio, R. H., Jackson, J. R., Dunton, B. C., \& Williams, C. J. (1995). Variability in automatic activation as an unobtrusive measure of racial attitudes: A bona fide pipeline? Journal of Personality and Social Psychology, 69, 1013-1027.

Federal Glass Ceiling Commission. (1995). Good for business: Making full use of the nation's human capital: The environmental scan: A factfinding report of the Federal Glass Ceiling Commission. Washington, DC: U.S. Government Printing Office.

Ferree, M. M. (1974). A woman for president? Changing responses, 1958-72. Public Opinion Quarterly, 38, 390-399.

Firth, M. (1982). Sex discrimination in job opportunities for women. Sex Roles, 8, 891-901.

Fiske, A. P., Haslam, N., \& Fiske, S. T. (1991). Confusing one person with another: What errors reveal about the elementary forms of social relations. Journal of Personality and Social Psychology, 60, 656-674.

Fiske, S. T. (1998). Stereotyping, prejudice, and discrimination. In D. T. Gilbert, S. T. Fiske, \& G. Lindzey (Eds.), The handbook of social psychology (4th ed., Vol. 2, pp. 357-411). Boston: McGraw-Hill.

Fiske, S. T., Bersoff, D. N., Borgida, E., Deaux, K., \& Heilman, M. E. (1991). Social science research on trial: Use of sex stereotyping research in Price Waterhouse v. Hopkins. American Psychologist, 46, 1049 1060.

Fiske, S. T., \& Stevens, L. E. (1993). What's so special about sex? Gender stereotyping and discrimination. In S. Oskamp \& M. Costanzo (Eds.), Gender issues in contemporary society (pp. 173-196). Thousand Oaks, CA: Sage.

Foddy, M., \& Smithson, M. (1999). Can gender inequalities be eliminated? Social Psychology Quarterly, 62, 307-324.

Fondas, N. (1997). Feminization unveiled: Management qualities in contemporary writings. Academy of Management Review, 22, 257-282.

Forsythe, S., Drake, M. F., \& Cox, C. E. (1985). Influence of applicant's dress on interviewer's selection decisions. Journal of Applied Psychology, 70, 374-378.

Foschi, M. (1996). Double standards in the evaluation of men and women. Social Psychology Quarterly, 59, 237-254.

Foschi, M. (2000). Double standards for competence: Theory and research. Annual Review of Sociology, 26, 21-42.

Foschi, M., Lai, L., \& Sigerson, K. (1994). Gender and double standards in the assessment of job applicants. Social Psychology Quarterly, 57, 326-339.

Garvin, D. A. (1993). Building a learning organization. Harvard Business Review, 71(4), 78-91.

Geis, F. L. (1993). Self-fulfilling prophecies: A social psychological view of gender. In A. E. Beall \& R. J. Sternberg (Eds.), The psychology of gender (pp. 9-54). New York: Guilford Press.

Genovese, M. A. (1993). Women as national leaders: What do we know? 
In M. A. Genovese (Ed.), Women as national leaders (pp. 177-210). Newbury Park, CA: Sage.

Giacolone, R. A., \& Riordan, C. A. (1990). Effect of self-presentation on perceptions and recognition in an organization. Journal of Psychology, $124,25-38$

Glick, P., \& Fiske, S. T. (1996). The Ambivalent Sexism Inventory: Differentiating hostile and benevolent sexism. Journal of Personality and Social Psychology, 70, 491-512.

Glick, P., \& Fiske, S. T. (2001). An ambivalent alliance: Hostile and benevolent sexism as complementary justifications for gender inequality. American Psychologist, 56, 109-118.

Goldberg, P. (1968). Are women prejudiced against women? Transaction, 5, 316-322.

Goldberg, S. (1993). Why men rule: A theory of male dominance. Chicago: Open Court.

Gomez-Mejia, L. R., McCann, J. E., \& Page, R. C. (1985). The structure of managerial behaviors and rewards. Industrial Relations, 24, 147-154.

Goodwin, S., Operario, D., \& Fiske, S. T. (1998). Situational power and interpersonal dominance facilitate bias and inequality. Journal of Social Issues, 54, 677-698.

Green, R. J., \& Ashmore, R. D. (1998). Taking and developing pictures in the head: Assessing the physical stereotypes of eight gender types. Journal of Applied Social Psychology, 28, 1609-1636.

Greenhaus, J. H., \& Parasuraman, S. (1999). Research on work, family, and gender: Current status and future directions. In G. N. Powell (Ed.), Handbook of gender \& work (pp. 391-412). Thousand Oaks, CA: Sage. Greenwald, A. G., McGhee, D. E., \& Schwartz, J. L. K. (1998). Measuring individual differences in implicit cognition: The Implicit Association Test. Journal of Personality and Social Psychology, 74, 1464-1480.

Gutek, B. A., \& Morasch, B. (1982). Sex-ratios, sex-role spillover, and sexual harassment of women at work. Journal of Social Issues, 38(4), $55-74$.

Hackman, J. R., \& Wageman, R. (1995). Total quality management: Empirical, conceptual, and practical issues. Administrative Science Quarterly, 40, 309-342.

Hall, J. A., \& Carter, J. D. (1999). Unpublished data. Northeastern University.

Hall, J. A., \& Friedman, G. B. (1999). Status, gender, and nonverbal behavior: A study of structured interactions between employees of a company. Personality and Social Psychology Bulletin, 25, 1082-1091.

Hall, R. J., Workman, J. W., \& Marchioro, C. A. (1998). Sex, task, and behavioral flexibility effects on leadership perceptions. Organizational Behavior and Human Decision Processes, 74, 1-32.

Halpert, J. A., Wilson, M. L., \& Hickman, J. L. (1993). Pregnancy as a source of bias in performance appraisals. Journal of Organizational Behavior, 14, 649-663.

Heatherington, L., Daubman, K. A., Bates, C., Ahn, A., Brown, H., \& Preston, C. (1993). Two investigations of "female modesty" in achievement situations. Sex Roles, 29, 739-754.

Hegstrom, J. L., \& Griffith, W. I. (1992). Dominance, sex, and leader emergence. Sex Roles, 27, 209-220.

Heilman, M. E. (1980). The impact of situational factors on personnel decisions concerning women: Varying the sex composition of the applicant pool. Organizational Behavior and Human Performance, 26, 386-395.

Heilman, M. E. (1983). Sex bias in work settings: The lack of fit model. Research in Organizational Behavior, 5, 269-298.

Heilman, M. E. (1995). Sex stereotypes and their effects in the workplace: What we know and what we don't know. Journal of Social Behavior and Personality, 10, 3-26.

Heilman, M. E. (2001). Description and prescription: How gender stereotypes prevent women's ascent up the organizational ladder. Journal of Social Issues, 57, 657-674.

Heilman, M. E., Block, C. J., \& Martell, R. F. (1995). Sex stereotypes: Do they influence perceptions of managers? Journal of Social Behavior and Personality, 10, 237-252.

Heilman, M. E., Block, C. J., Martell, R. F., \& Simon, M. C. (1989). Has anything changed? Current characterizations of men, women, and managers. Journal of Applied Psychology, 74, 935-942.

Heilman, M. E., Martell, R. F., \& Simon, M. C. (1988). The vagaries of sex bias: Conditions regulating the undervaluation, equivaluation, and overvaluation of female job applicants. Organizational Behavior and Human Decision Processes, 41, 98-110.

Heilman, M. E., \& Saruwatari, L. R. (1979). When beauty is beastly: The effects of appearance and sex on evaluations of job applicants for managerial and nonmanagerial jobs. Organizational Behavior and $\mathrm{Hu}$ man Decision Processes, 23, 360-372.

Heilman, M. E., \& Stopeck, M. H. (1985a). Attractiveness and corporate success: Different causal attributions for males and females. Journal of Applied Psychology, 70, 379-388.

Heilman, M. E., \& Stopeck, M. H. (1985b). Being attractive, advantage or disadvantage? Performance-based evaluations and recommended personnel actions as a function of appearance, sex, and job type. Organizational Behavior and Human Decision Processes, 35, 202-215.

Helgesen, S. (1990). The female advantage: Women's ways of leadership. New York: Doubleday.

Hembroff, L. A. (1982). Resolving status inconsistency: An expectation states theory and test. Social Forces, 61, 183-205.

Higgins, E. T. (1996). Knowledge activation: Accessibility, applicability, and salience. In E. T. Higgins \& A. W. Kruglanski (Eds.), Social psychology: Handbook of basic principles (pp. 133-168). New York: Guilford Press.

Hitt, M. A., Keats, B. W., \& DeMarie, S. M. (1998). Navigating in the new competitive landscape: Building strategic flexibility and competitive advantage in the 21st century. Academy of Management Executive, 12(4), 22-42.

Huddy, L., \& Terkildsen, N. (1993a). The consequences of gender stereotypes for women candidates at different levels and types of office. Political Research Quarterly, 46, 503-525.

Huddy, L., \& Terkildsen, N. (1993b). Gender stereotypes and the perception of male and female candidates. American Journal of Political Science, 37, 119-147.

Hunt, J. G., Boal, K. B., \& Sorenson, R. L. (1990). Top management leadership: Inside the black box. Leadership Quarterly, 1, 41-65.

Jackman, M. R. (1994). The velvet glove: Paternalism and conflict in gender, class, and race relations. Berkeley: University of California Press.

Jacobs, J. A. (1992). Women's entry into management: Trends in earnings, authority, and values among salaried managers. Administrative Science Quarterly, 37, 282-301.

Jacobsen, J. P. (1998). The economics of gender (2nd ed.). Malden, MA: Blackwell.

Jones, E. E., \& Pittman, T. S. (1982). Toward a general theory of strategic self-presentation. In J. Suls (Ed.), Psychological perspectives on the self (Vol. 1, pp. 231-262). Hillsdale, NJ: Erlbaum.

Juran, J. M. (1988). Juran on planning for quality. New York: Free Press.

Kanter, R. M. (1977). Men and women of the corporation. New York: Basic Books.

Kanter, R. M. (1997). Rosabeth Moss Kanter on the frontiers of management. Boston: Harvard Business School Press.

Kanter, R. M., Stein, B. A., \& Jick, T. D. (1992). The challenge of organizational change: How companies experience it and leaders guide it. New York: Free Press.

Kasof, J. (1993). Sex bias in the naming of stimulus persons. Psychological Bulletin, 113, 140-163.

Katz, D., \& Kahn, R. L. (1978). The social psychology of organizations (2nd ed.). New York: Wiley.

Katz, I., Wackenhut, J., \& Hass, R. G. (1986). Racial ambivalence, value 
duality, and behavior. In J. F. Dovidio \& S. L. Gaertner (Eds.), Prejudice, discrimination, and racism (pp. 35-59). San Diego, CA: Academic Press.

Kay, F. M., \& Hagan, J. (1998). Raising the bar: The gender stratification of law-firm capital. American Sociological Review, 63, 728-743.

Kelley, H. H. (1972). Attribution in social interaction. In E. E. Jones, D. E. Kanouse, H. H. Kelley, R. E. Nisbett, S. Valins, \& B. Weiner (Eds.), Attribution: Perceiving the causes of behavior (pp. 1-26). Morristown, NJ: General Learning Press.

Kenney, R. A., Schwartz-Kenney, B. M., \& Blascovich, J. (1996). Implicit leadership theories: Defining leaders described as worthy of influence. Personality and Social Psychology Bulletin, 22, 1128-1143.

Kent, R. L., \& Moss, S. E. (1994). Effects of sex and gender role on leader emergence. Academy of Management Journal, 37, 1335-1346.

Kolb, J. A. (1997). Are we still stereotyping leadership? A look at gender and other predictors of leader emergence. Small Group Research, 28, 370-393.

Kolb, J. A. (1999). The effect of gender role, attitude toward leadership, and self-confidence on leader emergence: Implications for leadership development. Human Resource Development Quarterly, 10, 305-320.

Korabik, K., Baril, G. L., \& Watson, C. (1993). Managers' conflict management style and leadership effectiveness: The moderating effects of gender. Sex Roles, 29, 405-420.

Kruglanski, A. W., \& Freund, T. (1983). The freezing and unfreezing of lay-inferences: Effects on impressional primacy, ethnic stereotyping, and numerical anchoring. Journal of Experimental Social Psychology, 19, 448-468.

Kruse, L., \& Wintermantel, M. (1986). Leadership Ms.-qualified: I. The gender bias in everyday and scientific thinking. In C. F. Graumann \& S. Moscovici (Eds.), Changing conceptions of leadership (pp. 171-197). New York: Springer-Verlag.

Kunda, Z., \& Sinclair, L. (1999). Motivated reasoning with stereotypes: Activation, application, and inhibition. Psychological Inquiry, 10, 1222.

Langford, T., \& MacKinnon, N. J. (2000). The affective bases for the gendering of traits: Comparing the United States and Canada. Social Psychology Quarterly, 63, 34-48.

Latham, G. P. (1986). Job performance and appraisal. In C. L. Cooper \& I. Robertson (Eds.), International review of industrial and organizational psychology (Vol. 1, pp. 117-155). London: Wiley.

Lauterbach, K. E., \& Weiner, B. J. (1996). Dynamics of upward influence: How male and female managers get their way. Leadership Quarterly, 7, 87-107.

Lee, D. M., \& Alvares, K. M. (1977). Effects of sex on descriptions and evaluations of supervisory behavior in a simulated industrial setting. Journal of Applied Psychology, 62, 405-410.

Lee, J., \& Hoon, T. H. (1993). Business students' perceptions of women in management-The case in Singapore. Management Education and Development, 24, 415-429.

Lenny, E. (1977). Women's self-confidence in achievement settings. Psychological Bulletin, 84, 1-13.

Levinson, R. M. (1982). Sex discrimination and employment practices: An experiment with unconventional job inquiries. In R. Kahn-Hut, A. N. Daniels, \& R. Colvard (Eds.), Women and work: Problems and perspectives (pp. 54-65). New York: Oxford University Press.

Lippa, R. (1998). The nonverbal judgment and display of extraversion, masculinity, femininity, and gender diagnosticity: A lens model analysis. Journal of Research in Personality, 32, 80-107.

Lips, H. M. (2000). College students' visions of power and possibility as moderated by gender. Psychology of Women Quarterly, 24, 39-43.

Loden, M. (1985). Feminine leadership or how to succeed in business without being one of the boys. New York: Times Books.

Lord, R. G., Foti, R. J., \& de Vader, C. L. (1984). A test of leadership categorization theory: Internal structure, information processing, and leadership perceptions. Organizational Behavior and Human Decision Processes, 34, 343-378.

Lord, R. G., \& Maher, K. J. (1993). Leadership and information processing: Linking perceptions and performance. New York: Routledge.

Lueptow, L. B., Garovich, L., \& Lueptow, M. B. (1995). The persistence of gender stereotypes in the face of changing sex roles: Evidence contrary to the sociocultural model. Ethology and Sociobiology, 16, $509-530$.

Luthar, H. K. (1996). Gender differences in evaluation of performance and leadership ability: Autocratic vs. democratic managers. Sex Roles, 35, $337-361$.

Lyness, K. S., \& Judiesch, M. K. (1999). Are women more likely to be hired or promoted into management positions? Journal of Vocational Behavior, 54, 158-173.

Lyness, K. S., \& Thompson, D. E. (1997). Above the glass ceiling? A comparison of matched samples of female and male executives. Journal of Applied Psychology, 82, 359-375.

Macrae, C. N., Hewstone, M., \& Griffiths, R. J. (1993). Processing load and memory for stereotype-based information. European Journal of Social Psychology, 23, 77-87.

Malloy, T. E., \& Janowski, C. L. (1992). Perceptions and metaperceptions of leadership: Components, accuracy, and dispositional correlates. Personality and Social Psychology Bulletin, 18, 700-708.

Martell, R. F. (1991). Sex bias at work: The effects of attentional and memory demands on performance ratings of men and women. Journal of Applied Social Psychology, 21, 1939-1960.

Martell, R. F. (1996). What mediates gender bias in work behavior ratings? Sex Roles, 35, 153-169.

Martell, R. F. (1999, May). Sensitive dependence in organizations: How just a little gender bias can cause the "glass ceiling" in organizations. Paper presented at the meeting of the Midwestern Psychological Association, Chicago.

Martell, R. F., Lane, D. M., \& Emrich, C. (1996). Male-female differences: A computer simulation. American Psychologist, 51, 157-158.

Martell, R. F., Parker, C., Emrich, C. G., \& Crawford, M. S. (1998). Sex stereotyping in the executive suite: "Much ado about something." Journal of Social Behavior and Personality, 13, 127-138.

Martin, P. Y. (1992). Gender, interaction, and inequality in organizations. In C. L. Ridgeway (Ed.), Gender, interaction, and inequality (pp. 208 231). New York: Springer-Verlag.

Massengill, D., \& di Marco, N. (1979). Sex-role stereotypes and requisite management characteristics: A current replication. Sex Roles, 5, 561570.

Maume, D. J., Jr. (1999). Glass ceilings and glass escalators: Occupational segregation and race and sex differences in managerial promotions. Work and Occupations, 1999, 483-509.

McIntyre, S., Moberg, D. J., \& Posner, B. Z. (1980). Preferential treatment in preselection decisions according to sex and race. Academy of Management Journal, 23, 738-749.

Melkas, H., \& Anker, R. (1997). Occupational segregation by sex in Nordic countries: An empirical investigation. International Labour Review, 136, 341-363.

Morris, M., \& Western, B. (1999). Inequality in earnings at the close of the twentieth century. Annual Review of Sociology, 25, 623-657.

Morrison, A. M., White, R. P., \& Van Velsor, E. (1987). Breaking the glass ceiling: Can women reach the top of America's largest corporations? Reading, MA: Addison-Wesley.

Moskowitz, D. S., Suh, E. J., \& Desaulniers, J. (1994). Situational influences on gender differences in agency and communion. Journal of Personality and Social Psychology, 66, 753-761.

Moss, S. E., \& Kent, R. L. (1996). Gender and gender-role categorization of emergent leaders: A critical review and comprehensive analysis. Sex Roles, 35, 79-96.

Mueller, C. (1986). Nurturance and mastery: Competing qualifications for 
women's access to high public office? Research in Politics and Society, 2, 211-232.

National Opinion Research Center. (1998). General social survey, 19721998: Cumulative study [CD-ROM]. Storrs, CT: Roper Center for Public Opinion Research.

Nemeth, C., Endicott, J., \& Wachtler, J. (1976). From the '50s to the '70s: Women in jury deliberations. Sociometry, 39, 293-304.

Newport, F. (2001, February 21). Americans see women as emotional and affectionate, men as more aggressive. Retrieved August 18, 2001, from the Gallup Poll News Service Web site: http://www.gallup.com/poll/ releases/pr010221.asp

Nieva, V. G., \& Gutek, B. A. (1980). Sex effects on evaluation. Academy of Management Review, 5, 267-276.

Nieva, V. G., \& Gutek, B. A. (1981). Women and work: A psychological perspective. New York: Praeger.

Offermann, L. R., \& Gowing, M. K. (1990). Organizations of the future: Changes and challenges. American Psychologist, 45, 95-108.

Ohlott, P. J., Ruderman, M. N., \& McCauley, C. D. (1994). Gender differences in managers' developmental job experiences. Academy of Management Journal, 37, 46-67.

Olian, J. D., Schwab, D. P., \& Haberfeld, Y. (1988). The impact of applicant gender compared to qualifications on hiring recommendations: A meta-analysis of experimental studies. Organizational Behavior and Human Decision Processes, 41, 180-195.

Olson, J. E., \& Frieze, I. H. (1987). Income determinants for women in business. In A. H. Stromberg, L. Larwood, \& B. A. Gutek (Eds.), Women and work: An annual review (Vol. 2, pp. 173-206). Thousand Oaks, CA: Sage.

Ott, E. M. (1989). Effects of the male-female ratio at work: Policewomen and male nurses. Psychology of Women Quarterly, 13, 41-57.

Paolillo, J. G. (1981). Manager's self assessments of managerial roles: The influence of hierarchical level. Journal of Management, 7, 43-52.

Parker, P. S., \& Ogilvie, D. T. (1996). Gender, culture, and leadership: Toward a culturally distinct model of African-American women executives' leadership strategies. Leadership Quarterly, 7, 189-214.

Pavett, C. M., \& Lau, A. W. (1983). Managerial work: The influence of hierarchical level and functional specialty. Academy of Management Journal, 26, 170-177.

Peters, L. H., Terborg, J. R., \& Taynor, J. (1974). Women As Managers Scale (WAMS): A measure of attitudes towards women in management positions. Catalog of Selected Documents in Psychology, 4, 27.

Peters, T. (1988). Restoring American competitiveness: Looking for new models of organizations. Academy of Management Executive, 2(2), 103-109.

Phillips, J. S., \& Lord, R. G. (1982). Schematic information processing and perception of leadership in problem-solving groups. Journal of Applied Psychology, 67, 486-492.

Plant, E. A., \& Devine, P. G. (1998). Internal and external motivation to respond without prejudice. Journal of Personality and Social Psychology, 75, 811-832.

Powell, G. N., \& Butterfield, D. A. (1979). The "good manager": Masculine or androgynous? Academy of Management Journal, 22, 395-403.

Powell, G. N., \& Butterfield, D. A. (1984). If "good managers" are masculine, what are "bad managers"? Sex Roles, 10, 477-484.

Powell, G. N., \& Butterfield, D. A. (1989). The "good manager": Did androgyny fare better in the 1980s? Group and Organization Studies, 14, 216-233.

Powell, G. N., \& Butterfield, D. A. (1994). Investigating the "glass ceiling" phenomenon: An empirical study of actual promotions to top management. Academy of Management Journal, 37, 68-86.

Price Waterhouse v. Hopkins, 825 F. 2nd 458 (D.C. Cir 1987).

Price Waterhouse v. Hopkins, 109 S. Ct. 1775 (1989).

Pugh, M. D., \& Wahrman, R. (1983). Neutralizing sexism in mixed-sex groups: Do women have to be better than men? American Journal of Sociology, 88, 746-762.

Ragins, B. R., \& Sundstrom, E. (1989). Gender and power in organizations: A longitudinal perspective. Psychological Bulletin, 105, 51-88.

Reskin, B. F., McBrier, D. B., \& Kmec, J. A. (1999). The determinants and consequences of workplace sex and race composition. Annual Review of Sociology, 25, 335-361.

Reskin, B. F., \& Ross, C. E. (1995). Jobs, authority, and earnings among managers: The continuing significance of sex. In J. A. Jacobs (Ed.), Gender inequality at work (pp. 127-151). Thousand Oaks, CA: Sage.

Ridgeway, C. L. (1978). Conformity, group-oriented motivation, and status attainment in small groups. Social Psychology, 41, 175-188.

Ridgeway, C. L. (1981). Nonconformity, competence, and influence in groups: A test of two theories. American Sociological Review, 46, 333-347.

Ridgeway, C. L. (1982). Status in groups: The importance of motivation. American Sociological Review, 47, 76-88.

Ridgeway, C. L. (1997). Interaction and the conservation of gender inequality: Considering employment. American Sociological Review, 62, $218-235$.

Ridgeway, C. L. (2001). Gender, status, and leadership. Journal of Social Issues, 57, 637-655.

Robinson, D. (1998). Differences in occupational earnings by sex. International Labour Review, 137, 3-31.

Rosen, B., \& Jerdee, T. H. (1973). The influence of sex-role stereotypes on evaluations of male and female supervisory behavior. Journal of Applied Psychology, 57, 44-48.

Rosen, B., \& Jerdee, T. H. (1974). Effects of applicant's sex and difficulty of job on evaluations of candidates for managerial positions. Journal of Applied Psychology, 59, 511-512.

Rosener, J. B. (1995). America's competitive secret: Utilizing women as a management strategy. New York: Oxford University Press.

Rosenwasser, S. M., \& Dean, N. G. (1989). Gender role and political office: Effects of perceived masculinity/femininity of candidate and political office. Psychology of Women Quarterly, 13, 77-85.

Rudman, L. A. (1998). Self-promotion as a risk factor for women: The costs and benefits of counterstereotypical impression management. Journal of Personality and Social Psychology, 74, 629-645.

Rudman, L. A., \& Glick, P. (1999). Feminized management and backlash toward agentic women: The hidden costs to women of a kinder, gentler image of middle managers. Journal of Personality and Social Psychology, 77, 1004-1010.

Rudman, L. A., \& Kilianski, S. E. (2000). Implicit and explicit attitudes toward female authority. Personality and Social Psychology Bulletin, 26, 1315-1328.

Russ, F. A., \& McNeilly, K. M. (1988). Has sex stereotyping disappeared? A study of perceptions of women and men in sales. Journal of Personal Selling and Sales Management, 8, 43-54.

Sapiro, V. (1983). The political integration of women: Roles, socialization, and politics. Urbana: University of Illinois Press.

Sapp, S. G., Harrod, W. J., \& Zhao, L. (1996). Leadership emergence in task groups with egalitarian gender-role expectations. Sex Roles, 34, 65-80.

Sarbin, T. R., \& Allen, V. L. (1968). Role theory. In G. Lindzey \& E. Aronson (Eds.), Handbook of social psychology (2nd ed., Vol. 1, pp. 488-567). Reading, MA: Addison-Wesley.

Schein, V. E. (1973). The relationship between sex role stereotypes and requisite management characteristics. Journal of Applied Psychology, 57, 95-100.

Schein, V. E. (1975). Relationships between sex role stereotypes and requisite management characteristics among female managers. Journal of Applied Psychology, 60, 340-344.

Schein, V. E. (2001). A global look at psychological barriers to women's progress in management. Journal of Social Issues, 57, 675-688. 
Schneer, J. A., \& Reitman, F. (1994). The importance of gender in mid-career: A longitudinal study of MBAs. Journal of Organizational Behavior, 15, 199-207.

Schneier, C. E., \& Bartol, K. M. (1980). Sex effects in emergent leadership. Journal of Applied Psychology, 65, 341-345.

Senge, P. M. (1990). The fifth discipline: The art and practice of the learning organization. New York: Doubleday.

Shackelford, S., Wood, W., \& Worchel, S. (1996). Behavioral styles and the influence of women in mixed-sex groups. Social Psychology Quarterly, 59, 284-293.

Sheppard, D. (1992). Women managers' perceptions of gender and organizational life. In A. J. Mills \& P. Tancred (Eds.), Gendering organizational analysis (pp. 151-166). Newbury Park, CA: Sage.

Simmons, W. W. (2001a, January 4). Majority of Americans say more women in political office would be positive for the country. Retrieved August 18, 2001, from the Gallup Poll News Service Web site: http:// www.gallup.com/poll/releases/pr010104.asp

Simmons, W. W. (2001b, January 11). When it comes to choosing a boss, Americans still prefer men. Retrieved August 18, 2001, from the Gallup Poll News Service Web site: http://www.gallup.com/poll/releases/ pr010111.asp

Sinclair, L., \& Kunda, Z. (2000). Motivated stereotyping of women: She's fine if she praised me but incompetent if she criticized me. Personality and Social Psychology Bulletin, 26, 1329-1342.

Skrypnek, B. J., \& Snyder, M. (1982). On the self-perpetuating nature of stereotypes about women and men. Journal of Experimental Social Psychology, 18, 277-291.

Snyder, M. (1981). On the self-perpetuating nature of social stereotypes. In D. L. Hamilton (Ed.), Cognitive processes in stereotyping and intergroup behavior (pp. 183-212). Hillsdale, NJ: Erlbaum.

Solberg, E. J. (1999). Using occupational preference in estimating market wage discrimination: The case of the gender pay gap (decomposition of a reduced-form wage equation). American Journal of Economics and Sociology, 58, 85-113.

Spence, J. T., \& Buckner, C. E. (2000). Instrumental and expressive traits, trait stereotypes, and sexist attitudes. Psychology of Women Quarterly, 24, 44-62.

Spence, J. T., \& Hahn, E. D. (1997). The Attitudes Toward Women Scale and attitude change in college students. Psychology of Women Quarterly, 21, 17-34.

Spence, J. T., \& Helmreich, R. L. (1978). Masculinity \& femininity: Their psychological dimensions, correlates, \& antecedents. Austin: University of Texas Press.

Spencer, S. J., Steele, C. M., \& Quinn, D. M. (1999). Stereotype threat and women's math performance. Journal of Experimental Social Psychology, 35, 4-28.

Spurr, S. J. (1990). Sex discrimination in the legal profession: A study of promotion. Industrial and Labor Relations Review, 43, 406-417.

Stangor, C., Lynch, L., Duan, C., \& Glass, B. (1992). Categorization of individuals on the basis of multiple social features. Journal of Personality and Social Psychology, 62, 207-218.

Stanley, T. D., \& Jarrell, S. B. (1998). Gender wage discrimination bias? A meta-regression analysis. Journal of Human Resources, 33, 947-973.

Steele, C. M. (1997). A threat in the air: How stereotypes shape intellectual identity and performance. American Psychologist, 52, 613-629.

Stevens, C. K., \& Kristof, A. L. (1995). Making the right impression: A field study of applicant impression management during job interviews. Journal of Applied Psychology, 80, 587-606.

Stroh, L. K., Brett, J. M., \& Reilly, A. H. (1992). All the right stuff: A comparison of female and male managers' career progression. Journal of Applied Psychology, 77, 251-260.

Survey Research Consultants International. (1998). Index to international public opinion, 1996-1997. Westport, CT: Greenwood Press.
Sutton, C. D., \& Moore, K. K. (1985). Executive women-20 years later. Harvard Business Review, 63(6), 42-66.

Swim, J., Borgida, E., Maruyama, G., \& Myers, D. G. (1989). Joan McKay versus John McKay: Do gender stereotypes bias evaluations? Psychological Bulletin, 105, 409-429.

Swim, J. K., \& Sanna, L. J. (1996). He's skilled, she's lucky: A metaanalysis of observers' attributions for women's and men's successes and failures. Personality and Social Psychology Bulletin, 22, 507-519.

Tannen, D. (1994). Talking from 9 to 5: Women and men in the workplace: Language, sex, and power. New York: Morrow.

Taylor, S. E., \& Fiske, S. T. (1978). Salience, attention, and attribution: Top of the head phenomena. In L. Berkowitz (Ed.), Advances in experimental social psychology (Vol. 11, pp. 249-288). New York: Academic Press.

Taynor, J., \& Deaux, K. (1973). When women are more deserving than men: Equity, attribution, and perceived sex differences. Journal of Personality and Social Psychology, 28, 360-367.

Terborg, J. R., Peters, L. H., Ilgen, D. R., \& Smith, F. (1977). Organizational and personal correlates of attitudes toward women as managers. Academy of Management Journal, 20, 89-100.

Tomkiewicz, J., \& Adeyemi-Bello, T. (1995). A cross-sectional analysis of the attitudes of Nigerians and Americans toward women as managers. Journal of Social Behavior and Personality, 10, 189-198.

Tosi, H. L., \& Einbender, S. W. (1985). The effects of the type and amount of information in sex discrimination research: A meta-analysis. Academy of Management Journal, 28, 712-723.

Townsend, B. (1996). Room at the top for women. American Demographics, $18,28-37$.

Twenge, J. M. (1997). Attitudes toward women, 1970-1995: A metaanalysis. Psychology of Women Quarterly, 21, 35-51.

U.S. Bureau of the Census. (2000). Current population reports: Educational attainment in the United States: March 2000 (Table 1: Educational attainment of the population 15 years and over, by age, sex, race, and Hispanic origin). Retrieved June 6, 2001, from http://www.census. gov/population/socdemo/education/p20-536/tab01.txt

U.S. Bureau of Labor Statistics. (2001a). Annual average tables from the January 2001 issue of Employment and Earnings (Table 11: Employed persons by detailed occupation, sex, race, and Hispanic origin). Retrieved August 18, 2001, from http://www.bls.gov/cpsaatab.htm

U.S. Bureau of Labor Statistics. (2001b). News: The employment situation: July 2001 (Table A-1: Employment status of the civilian population by sex and age). Retrieved August 18, 2001, from http://www.bls.gov/ news.release/pdf/empsit.pdf

U.S. Department of Defense. (1998). Active duty military personnel by service by rank/grade (for September 30, 1997). Retrieved September 8, 1999, from http://web1.whs.osd.mil/mmid/military/miltop.htm

U.S. General Accounting Office. (1998). Gender issues: Analysis of promotion and career opportunities data (GAO/NSIAD-98-157). Washington, DC: U.S. General Accounting Office.

van Knippenberg, A., van Twuyver, M., \& Pepels, J. (1994). Factors affecting social categorization processes in memory. British Journal of Social Psychology, 33, 419-431.

Van Vianen, A. E. M., \& Fischer, A. H. (2000). Illuminating the glass ceiling: The role of organizational culture preferences. Unpublished manuscript, University of Amsterdam, Amsterdam, The Netherlands.

Volberda, H. W. (1998). Building the flexible firm: How to remain competitive. New York: Oxford University Press.

von Hippel, W., Sekaquaptewa, D., \& Vargas, P. (1995). On the role of encoding processes in stereotype maintenance. In M. Zanna (Ed.), Advances in experimental social psychology (Vol. 27, pp. 177-254). San Diego, CA: Academic Press.

Wagner, D. G., Ford, R. S., \& Ford, T. W. (1986). Can gender inequalities be reduced? American Sociological Review, 51, 47-61.

Walker, H. A., Ilardi, B. C., McMahon, A. M., \& Fennell, M. L. (1996). 
Gender, interaction, and leadership. Social Psychology Quarterly, 59, 255-272.

Watson, C. (1988). When a woman is the boss: Dilemmas in taking charge. Group and Organization Studies, 13, 163-181.

Weinraub, B. (1997, December 22). Dawn Steel, studio chief and producer, dies at 51. New York Times, p. A18.

Wiley, M. G., \& Eskilson, A. (1985). Speech style, gender stereotypes, and corporate success: What if women talk more like men? Sex Roles, 12, 993-1007.

Williams, C. L. (1992). The glass escalator: Hidden advantages for men in the "female" professions. Social Problems, 39, 253-267.

Williams, C. L. (1995). Still a man's world: Men who do "women's work.” Berkeley: University of California Press.

Williams, J. E., \& Best, D. L. (1990a). Measuring sex stereotypes: A multination study. Newbury Park, CA: Sage.

Williams, J. E., \& Best, D. L. (1990b). Sex and psyche: Gender and self viewed cross-culturally. Newbury Park, CA: Sage.

Williams, J. E., Satterwhite, R. C., \& Best, D. L. (1999). Pancultural gender stereotypes revisited: The Five Factor Model. Sex Roles, 40, 513-525.

Wood, R. G., Corcoran, M. E., \& Courant, P. N. (1993). Pay differences among the highly paid: The male-female earnings gap in lawyers' salaries. Journal of Labor Economics, 11, 417-441.
Wood, W. (1987). Meta-analytic review of sex differences in group performance. Psychological Bulletin, 102, 53-71.

Wood, W., Christensen, P. N., Hebl, M. R., \& Rothgerber, H. (1997). Conformity to sex-typed norms, affect, and the self-concept. Journal of Personality and Social Psychology, 73, 523-535.

Wood, W., \& Karten, S. J. (1986). Sex differences in interaction style as a product of perceived sex differences in competence. Journal of Personality and Social Psychology, 50, 341-347.

Wood, W., Polek, D., \& Aiken, C. (1985). Sex differences in group task performance. Journal of Personality and Social Psychology, 48, 63-71.

Wosinska, W., Dabul, A. J., Whetstone-Dion, R., \& Cialdini, R. B. (1996). Self-presentational responses to success in the organization: The costs and benefits of modesty. Basic and Applied Social Psychology, 18, 229-242.

Yoder, J. D. (1991). Rethinking tokenism: Looking beyond numbers. Gender and Society, 5, 178-192.

Yoder, J. D., \& Sinnett, L. M. (1985). Is it all in the numbers? A case study of tokenism. Psychology of Women Quarterly, 9, 413-418.

Received July 29, 1999

Revision received June 29, 2001

Accepted July 30, 2001

\section{Wanted: Your Old Issues!}

As APA continues its efforts to digitize journal issues for the PsycARTICLES database, we are finding that older issues are increasingly unavailable in our inventory. We are turning to our long-time subscribers for assistance. If you would like to donate any back issues toward this effort (preceding 1982), please get in touch with us at journals@apa.org and specify the journal titles, volumes, and issue numbers that you would like us to take off your hands. 